TITLE:

\title{
The Role of Renewable Energy Resources in Sustainability of Water Desalination as a Potential Fresh- Water Source: An Updated Review
}

\section{AUTHOR(S):}

Ahmadi, Esmaeil; McLellan, Benjamin;

Mohammadi-Ivatloo, Behnam; Tezuka, Tetsuo

\section{CITATION:}

Ahmadi, Esmaeil ... [et al]. The Role of Renewable Energy Resources in Sustainability of Water Desalination as a Potential Fresh-Water Source: An Updated Review. Sustainability 2020, 12(13): 5233.

\section{ISSUE DATE:}

2020-06-28

URL:

http://hdl.handle.net/2433/254075

\section{RIGHT:}

(c) 2020 by the authors. Licensee MDPI, Basel, Switzerland. This article is an open access article distributed under the terms and conditions of the Creative Commons Attribution (CC BY) license (http://creativecommons.org/licenses/by/4.0/). 
Article

\title{
The Role of Renewable Energy Resources in Sustainability of Water Desalination as a Potential Fresh-Water Source: An Updated Review
}

\author{
Esmaeil Ahmadi ${ }^{1, *(\mathbb{D})}$, Benjamin McLellan ${ }^{1}\left(\mathbb{D}\right.$, Behnam Mohammadi-Ivatloo $^{2,3, * \mathbb{C}}$ \\ and Tetsuo Tezuka ${ }^{1}$ \\ 1 Energy Economics Laboratory, Graduate School of Energy Science, Kyoto University, Kyoto 606-8501, Japan; \\ b-mclellan@energy.kyoto-u.ac.jp (B.M.); tezuka@energy.kyoto-u.ac.jp (T.T.) \\ 2 Faculty of Electrical and Computer Engineering, University of Tabriz, Tabriz 5157944533, Iran \\ 3 Institute of Research and Development, Duy Tan University, Da Nang 550000, Vietnam \\ * Correspondence: esmaeil.ahmadi.53s@st.kyoto-u.ac.jp (E.A.); mohammadi@ieee.org (B.M.-I.)
}

Received: 30 May 2020; Accepted: 22 June 2020; Published: 28 June 2020

check for updates

\begin{abstract}
Desalination is becoming a practical option to meet water demand in an increasing number of locations that are facing water scarcity. Currently, more than 150 countries in the world are already using desalination technologies, which account for about one percent of the world's drinking water. Although for specific regions, desalination is the only feasible solution to close the supply-demand gap (for example the production of desalinated seawater in the Middle East is predicted to rise almost fourteen-fold by 2040), the sustainability of desalination systems is still remarkably under question. This review aims first to investigate the technical and economic trends and environmental and social aspects of desalination systems and then, in the second stage, to give an overview of the role of renewable energy technologies in the sustainability of the future water systems with an increasing share of desalination.
\end{abstract}

Keywords: sustainability; desalination; renewable energy; water-energy-nexus

\section{Introduction}

Water is vital to life, society and the economy. A study in 2016 [1] found that around 4 billion of the global population are facing moderate to severe water scarcity, about $66 \%$ of which live under conditions of severe water scarcity for at least one month during a year. A United Nations' report [2] predicted that under average economic growth without improvement in efficiency, global freshwater demand could reach 40 percent above the current demand by 2030. The current pace of efficiency improvement is globally too slow to meet future demand. Authors [3] estimated that by considering the ongoing improvements in water efficiency, only 20 percent of the supply-demand gap would be closed. On the other hand, the potential remaining natural water resources, which are sustainable to utilize, are limited. Beyond risks from climate change, supply-side options to meet future water demand face rising costs due to steep marginal costs [4]. This study seeks to identify the state-of-art of desalination-based water provision, considered from a wide variety of perspectives beyond just the techno-economic analysis. It aims to identify the promising advantages of desalination technologies, particularly in connection with the energy-water nexus, and to clarify the identified disadvantages as shown through a critical review of recent studies.

There are non-conventional options, such as desalination and reuse of wastewater, which are the ultimate solution to meet water demand in specific regions. Rapidly progressing desalination technologies and market maturation have led to a significant drop in desalination costs, and the 
environmental impacts of the desalination process are progressively being mitigated. Even though desalination costs are likely to remain more expensive than other traditional water options, it increasingly will be considered as an option in specific areas due to climate change, natural and physical water scarcity, freshwater resource security, and the need to improve access to clean water (health problems).

Climate change is likely to impose a greater incidence of drought due to more limited and unpredictable rainfall and a higher rate of evaporation due to rising temperatures. This rising temperature could also cause an increase in water demand, exacerbating competition among agriculture, municipal, and industrial users. Desalination is a solution to enhance climate change resilience.

Additionally, desalination is economically and politically important to achieve self-reliance for specific areas. Israel and Singapore are examples where investments in desalination have been made to reduce their dependency on imported water due to their geopolitical situation. Furthermore, with population growth, providing quality water for cities becomes a challenge for policy-makers. Supplying water to dynamic sectors of the economy, namely commercial and industrial users, is an economic priority. Any failure in providing water to these sectors leads to high economic, social, and political costs. Desalination is considered a secure supply with high reliability for these water demands.

As a result, desalination is becoming an economical and practical option to meet water demand in an increasing number of locations. Currently, more than 150 countries in the world are already using desalination technologies, which account for about one percent of the world's drinking water [5]. A multi-criteria analysis in Kuwait [6] showed that among management options and strategic policies to meet future water demand, desalination powered by renewable resources and wastewater reuse ranked the highest. Based on Figure 1c, municipal and industrial sectors account for the main share of desalinated water production worldwide .
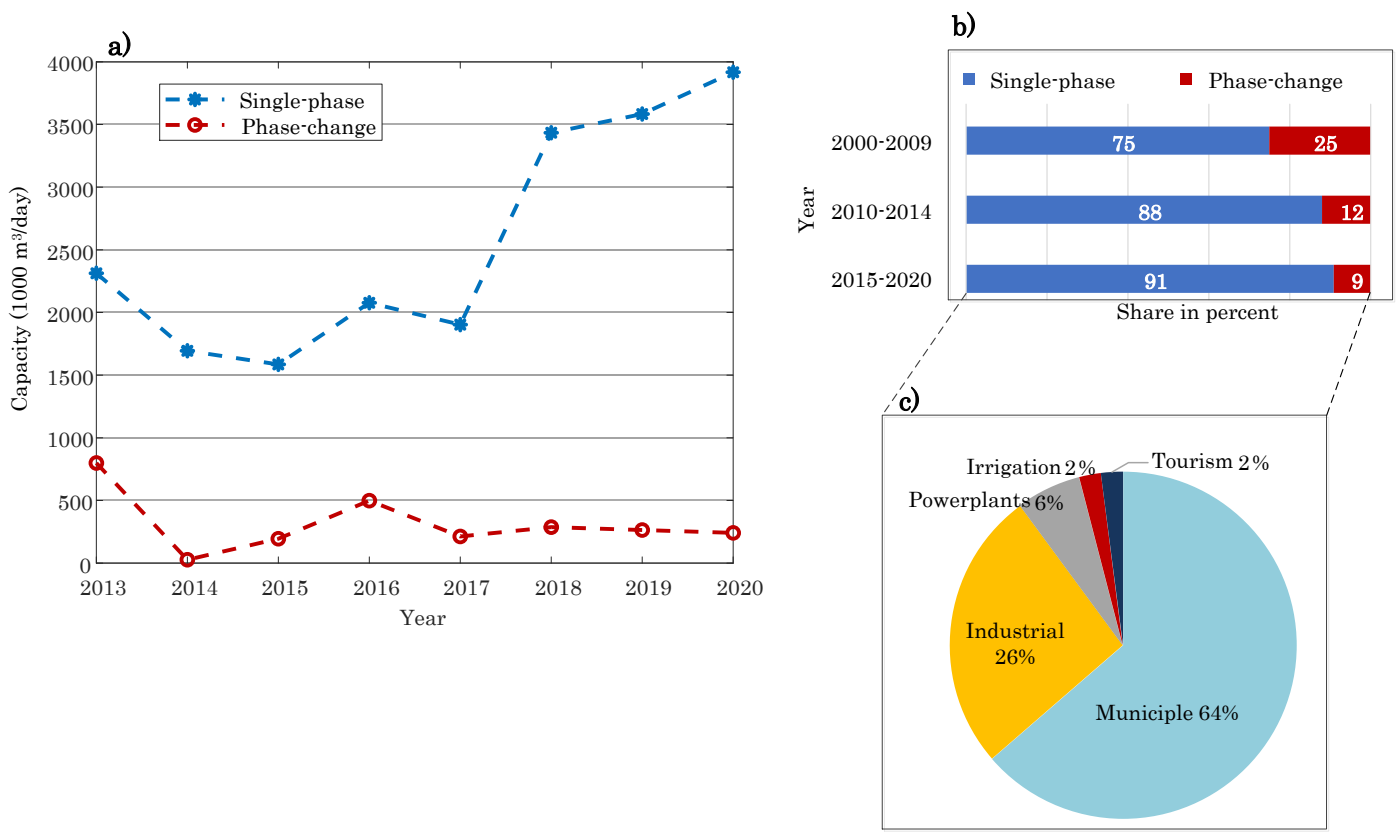

Figure 1. Total worldwide installed desalination: (a) capacity by technology; (b) technology share; and (c) share of each user for worldwide desalinated water [7].

On the other hand, the total world energy consumption has been forecast to increase by $44 \%$ from 2006 to 2030, according to a report by the US Department of Energy [8]. Desalination is an energy-intensive process. Energy requirement in commercial desalination processes ranges from a minimum of $1.8 \mathrm{KWh} / \mathrm{m}^{3}$ for reverse osmosis technology to a maximum of $12.5 \mathrm{KWh} / \mathrm{m}^{3}$ for multi-stage flash technology [4,9]. On average, desalinating $1000 \mathrm{~m}^{3}$ of saline water by conventional technologies consumes about 37 barrels of crude oil (utilizing combined cycle power plant and reverse osmosis desalination technology), which causes around 10 tons of $\mathrm{CO}_{2}$ emissions [10]. According 
to the World Energy Outlook 2016, in the Middle East, the water sector's share of total electricity consumption is expected to increase from $9 \%$ in 2015 to $16 \%$ by 2040, because of a rise in desalination capacity [11]. Furthermore, the energy sector is also set to become thirstier over the next decades, with energy-related water consumption increasing by nearly 60\% between 2014 and 2040 .

Studies have investigated different aspects of the sustainability of water systems and energy systems. The authors of [12] proposed a multi-objective optimization method for the sustainable utilization of energy resources, underground freshwater, and desalinated water. A study [13] explored 12 sample cities in Southeast Europe based on the sustainable development of energy, water, and environment systems. Although this study examined the cities based on a vast range of indicators, the linkage and relations between these indicators have not been evaluated, and the energy and water sectors were studied in isolation.

Based on the technical and economical aspects, other authors [14] applied system dynamics to predict the water and energy demands for a region in China from 2015 to 2030. In the next step, this study investigated the correlation between the risk of availability of energy and water. Another study [15] introduced a simplified method to track the water-energy nexus for a city in China. In this method, the required water for energy generation and required energy for the water sector were calculated in detail and compared with an average, which was obtained from government data. Others [16] developed a tool to calculate the electricity intensity of the water sector in California, USA. The study introduced a bottom-up model to calculate and visualize electricity consumption of the water sector for each person and each cubic meter of water as the energy intensity of the water sector. The result of this study indicated that considering the whole state uniformly for studying electricity intensity of the water sector was not practical because of geographical and climate differences.

Greenhouse gas (GHG) emissions of the water sector are typically the main focal point of studies on environmental impacts. Authors [17] investigated the budget-based plans for $\mathrm{CO}_{2}$ mitigation and water management at the city-level. The budget-based plans for 13 cities in the USA and the UK were studied. This study proposed recommendations to improve existing and future carbon and water budget programs, indicating that the plans focus primarily on GHG (greenhouse gas) emissions mitigation while ignoring water-energy linkages and challenges due to water resource depletion. The authors of [18] developed a life cycle assessment to study GHG emissions from water resources, including imported water, seawater desalination, brackish groundwater desalination, and recycled water in California, USA. This study found that desalination, coupled with a concentrated solar power (CSP) system, has lower GHG emissions than that of recycled and imported water. Study [19] investigated the energy consumption and $\mathrm{CO}_{2}$ emissions from the water system in Mexico City, Mexico. The water system in this study was divided into two categories, including water supply and wastewater. Water supplies for this city consist of two groundwater and two surface sources. Due to the long distance from two of the water sources, about 90 percent of the total energy consumption in the water sector was related to water supply. Several solutions proposed to decrease water consumption, the most effective of which are non-revenue water, water pricing reforms, and implementation of rainwater harvesting. Non-revenue water here refers to all water lost to leakage and other losses (such as illegal connections and metering errors), which was reported to be about $40 \%$ for Mexico City. In this study, the possible future changes in water demand patterns and energy resources mix (more 90 percent from fossil fuel resources) were not considered.

Authors [20] reviewed quantitative modeling scenarios for sustainable energy pathways and showed a gap in these models, which is not considering the social aspects of sustainability in quantitative technical models. Several models introduced the using of system dynamics, and expressed that taking into account the social aspects (for example, technology adaption by society) makes pathways more realistic. A study [21] highlighted the roles of economic development, technological innovation, and policy-making in shaping national energy transitions. The authors in [22] developed a system dynamics model to study the interactions between urban water and energy systems. The influence of end-use water consumers on the upstream of the water and energy sectors was 
investigated in London, UK, as a case study. The results indicated that policy targets, such as decarbonization plans, and social aspects, such as quality of life, when incorporated into models, assisted in achieving more realistic models.

All of these studies highlighted the interlinkages between the energy sector and the water sector towards sustainability. Although the deployment rate of desalination systems has accelerated recently and considering recent developments discussed in the literature that reveal that desalination can be affordable, the sustainability of these systems is still under question. Contributions that meaningfully address the technical, economic, environmental, and social issues of desalination are required in this era of water stress in order to achieve sustainable desalination in the future. This review aims to give an overview of the role of renewable energy technologies in the sustainability of future water systems with an increasing share of desalination. In other words, this study highlights the interlinkages and nexus between renewables and desalination.

Different aspects of sustainability are discussed in the following sections. In Section 2, the technical factors and current desalination technologies and their features are clarified. Section 3 highlights the factors which are important in desalination costs and gives an overview of the trend of renewable desalination technologies. Section 4 investigates the environmental impacts. Afterward, in Section 5, the social factors are discussed, and the potential synergy of powering desalination by renewables in order to raise social acceptance is examined. Finally, Section 6 summarizes the main concluding points of this study and proposes some frameworks for future studies.

\section{Technical Aspect}

\subsection{Desalination Technologies}

The desalination technologies are divided into two categories: desalination with phase-change or thermal processes and desalination with single-phase or membrane processes. The phase-change desalination technologies include multi-stage flash (MSF), multiple-effect distillation (MED), vapor compression (VC), and freezing. Reverse osmosis (RO), electrodialysis (ED), capacitive deionization (CDI), and membrane distillation (MD) are examples of the single-phase desalination technologies. Reverse osmosis, multi-stage flash, multiple-effect distillation, electrodialysis, and hybrid technologies are commercially viable and commonly used desalination technologies with a share of $63 \%, 23 \%, 8 \%$, $3 \%$, and $3 \%$, respectively [23].

Currently, multi-stage flash distillation (MSF) and multi-effect distillation (MED), reverse osmosis, and a combination of these technologies (hybrid desalination) are the dominant technologies for seawater desalination.

\subsubsection{Phase-Change Desalination}

The primary energy required for phase change technologies is thermal energy. MSF, MED, and vapor compression (VC), which could be mechanical (MVC) or thermal (TVC), are the most commercially available technologies in this category [24]. In the MSF process, vapor is generated by a sudden pressure reduction of seawater or brine when saline water enters an evacuated chamber stage by stage. MED is based on vapor generation using the absorption of thermal energy by saline water. In the VC process, after the generation of vapor from saline water, this vapor is converted into freshwater by thermal or mechanical compression.

The separation process in the desalination of water by freezing follows the solid-liquid phase-change phenomenon. In this process, the temperature of saline water is reduced to the freezing point, which ice crystals of pure water are formed within the salt solution. Refrigeration systems are used in this process to reduce the temperature. In the next step, these crystals can be separated and washed. A humidification/dehumidification $(\mathrm{H} / \mathrm{DH})$ process captures the water vapor, which is mixed with air. In this method, brine is used to increase the humidity in an air stream. In the next stage, 
freshwater is collected by condensing this humid air on the surface of cool coils. H/DH technologies have not matured industrially due to technical barriers [24].

\subsubsection{Single-Phase Desalination}

The primary types of energy needed for membrane-based desalination are electricity and hydraulic pressure. Reverse osmosis, electrodialysis and membrane distillation (MD) technologies are the most commonly utilized in this category. In the RO processes, electricity or shaft power is needed to drive high-pressure pumps. For the RO process, mechanical pressure is applied to overcome osmotic pressure and separate salt of saline water. In the ED process, electricity is used for the ionization of salts contained in the seawater. The membrane distillation process includes two streams: one hot saline stream and a cool freshwater stream. Water vapor is transported between these two streams because of a temperature difference of streams. With a 80 percent water recovery rate, ED technology has better performance compared to $\mathrm{RO}$ technology, which has about a 40 to 50 percent recovery rate. Capacitive deionization (CDI) is a novel desalination technology suitable for brackish water treatment with a low level of salinity [25]. CDI technology operates by applying a relatively low potential (around 1-1.5 V) to drive ions from brackish water to a charged electrode with a porous structure using static electrical force, thereby separating the salt from brackish water [26].

\subsubsection{Hybrid Desalination}

Hybrid desalination plants are typically co-located with power plants so as to use waste heat for a thermal desalination facility (MSF or MED) and a combination of a RO desalination plant. Combined thermal and RO plants are usually suitable for situations with wide diurnal or seasonal variation in power or water demand. In such countries, peak power demand during summer is 30 to 40 percent higher than the maximum power demand in winter. In the Middle East, this difference reaches up to 50 percent, while the demand for desalinated water is almost constant. Switching between the $\mathrm{RO}$ and thermal plants allows benefiting from cheap available energy, thus leading to the cheapest desalination process.

\subsection{Renewable Energy and Desalination}

Among renewable resources, hydropower and biomass sources are not suitable to combine with desalination technologies due to the requirement for water resources, which is limited in regions facing water scarcity. The authors in study [27] considered biomass resources to reduce the $\mathrm{CO}_{2}$ footprint of desalination plants in Saudi Arabia but did not mentioned the source or type of biomass. In areas with abundant solar irradiance, the main focus has been on integrating the desalination process and solar energy since water scarcity is more likely to occur in these regions [28]. Solar energy, with 51 percent of worldwide renewable desalination capacity, has the highest share, following wind energy, which accounts for 30 percent [29]. Figure 2a,b shows the integration of desalination technologies with renewable energy resources and the share of each renewable technology in desalination worldwide. Geothermal and wave and tidal resources are the other options to couple with renewable resources, which are still in the research phase and are not yet economically feasible [10].

Previous studies [30] investigated co-locating pumped hydro storage systems with reverse osmosis desalination plants based on geographical and economic benchmarks in several cities in the USA, Iran, China, and Chile. The results indicated that pumped hydro systems can compensate for the intermittent nature of power production from photovoltaic panels and wind turbines and decrease the energy intensity needed for reverse osmosis plants. Average daily historical data were used for calculating the renewable energy (RE) production for a whole year, which did not describe the renewable production with sufficient accuracy to calculate the fluctuations resulting due to the intermittent nature of renewable power production. The authors in another study [31] proposed a spatial model to assess potential technical and economical viable site locations for desalination facilities powered by renewables (wind and solar). Depth of water resource, distance to current water facilities, 
salinity degree, the magnitude of local RE resources, and local water price were considered as criteria in this model. Among 1445 site locations, 193 site locations were recognized as economically viable for RO desalination facilities, 145 of which were wind-powered desalination units. Solar-powered units were preferable at the remaining 48 sites.

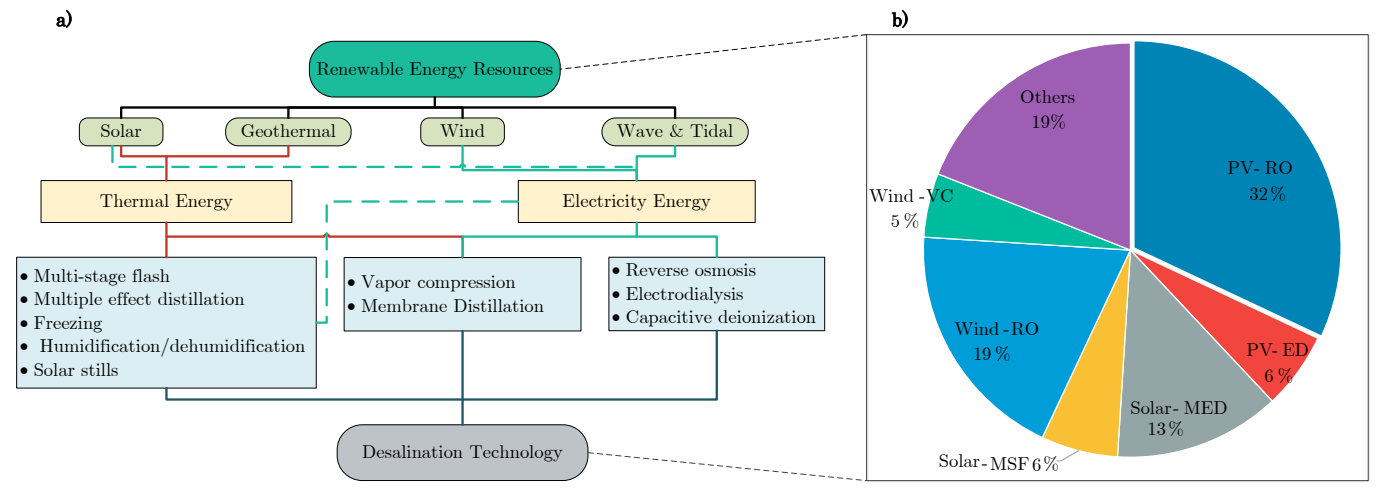

Figure 2. (a) The integration of desalination technologies with RE. (b) The share of renewable energy technologies in worldwide renewable-powered desalination processes in 2017.

There are three categories of technologies to harness ocean energy: thermal, mechanical, and chemical or salt gradient. The ocean mechanical (tidal and wave energy) and thermal energy technologies are more advanced than ocean chemical energy technology. Integrating the thermal energy technologies with phase-change desalination processes and using direct ocean mechanical energy (tidal, wave, and current energy) without transforming to electricity in desalination methods (which need hydraulic pressure) could improve the efficiency and economic feasibility of the integrated systems. Ocean salt gradient technology is still far away from being a reality. However, in the future, ocean salinity gradient energy is a promising ocean energy source, since the forward osmosis, pressure retarded osmosis, and reverse electrodialysis devices can be readily integrated into current desalination technologies as a recovery energy system without major reconstruction in plants. There are several limitations to developing ocean-based power generation, including technological and economic limitations of energy harvesting and transport and device maintenance underwater. Having said that, using ocean energy in desalination applications could solve the ocean energy technological defects relating to economic limitations by co-location in the future [23].

Solar thermal and geothermal resources are water-consuming resources. Water availability is an essential factor that must be considered to assess the potential of these resources in each region, which has not been considered in the majority of studies like [32,33]. A study examined the extent to which physical water scarcity can limit the deployment of geothermal and solar thermal energy resources to produce electricity in California [34]. This study first calculated the sustainable amount of extraction from the water resources and then determined the supportable capacity of these power plants from the available water supply based on technology and cooling type by 2050. For several areas in California, the estimated capacity of geothermal and solar thermal resources was found to be limited due to insufficient water availability, and without considering water limitations the assessment would not be realistic.

Table 1 indicates the renewable energy resources used for desalination purposes . As an example, thermal collectors produced thermal energy for sanitary hot water in study [35], which is not mentioned in this table; only solar and wind electricity powering the desalination system are indicated as energy resources for this study in Table 1 . This table shows that solar and wind electricity are the most common sources of renewable energy for desalination among studies. RO desalination technology is the dominant technology that has been studied the most (56 studies). MSF desalination technology, which requires high temperatures for the process, is not popular among studies (two studies in the Middle East and another one in the American region) compared to MED technology (nine studies), which operates at low temperatures. 
Table 1. Renewable energy resources used for desalination purpose. RO: reverse osmosis; MED: multiple-effect distillation; MVC: mechanical vapor compression; MSF: multi-stage flash; ED: electrodialysis.

\begin{tabular}{|c|c|c|c|c|c|c|c|c|c|c|c|}
\hline \multirow[t]{2}{*}{ Model Type } & \multicolumn{8}{|c|}{ Energy Resource } & \multirow[t]{2}{*}{$\begin{array}{l}\text { Desalination } \\
\text { Technology }\end{array}$} & \multirow[t]{2}{*}{ Scale } & \multirow[t]{2}{*}{ Ref. } \\
\hline & Solar Electricity & Solar Thermal & Wind Turbine & Geothermal & Ocean Energy & Hydro Power & Diesel Generator & Hydrogen & & & \\
\hline \multirow{30}{*}{ On-grid } & $\checkmark$ & - & - & - & - & - & - & - & RO & Full plant & [36] \\
\hline & $\checkmark$ & - & - & - & - & - & - & - & RO & Pilot scale & [37] \\
\hline & $\checkmark$ & - & - & - & - & - & - & - & $\mathrm{RO}$ & Full plant & [38] \\
\hline & $\checkmark$ & - & $\checkmark$ & - & - & - & - & - & RO and MED & Full plant & [39] \\
\hline & $\checkmark$ & - & - & - & - & - & - & - & RO & Full plant & [40] \\
\hline & $\checkmark$ & - & $\checkmark$ & - & - & - & $\checkmark$ & $\checkmark$ & RO & Pilot scale & [41] \\
\hline & $\checkmark$ & - & - & - & - & - & - & - & RO & Pilot scale & [42] \\
\hline & $\checkmark$ & - & $\checkmark$ & - & - & - & - & - & RO & Pilot scale & [43] \\
\hline & $\checkmark$ & - & $\checkmark$ & - & - & - & - & - & RO & Full plant & [44] \\
\hline & $\checkmark$ & - & $\checkmark$ & - & - & - & - & - & $\mathrm{RO}, \mathrm{MVC}$ & Pilot scale & [45] \\
\hline & $\checkmark$ & $\checkmark$ & - & - & - & - & - & - & RO & Full plant & [46] \\
\hline & - & - & - & - & 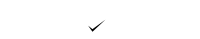 & - & - & - & RO & Pilot scale & [47] \\
\hline & $\checkmark$ & - & $\checkmark$ & - & - & - & - & - & RO & Pilot scale & [48] \\
\hline & $\checkmark$ & - & $\checkmark$ & - & - & - & - & - & RO & Pilot scale & [49] \\
\hline & 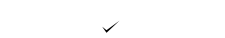 & - & 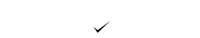 & - & - & - & - & - & $\mathrm{RO}$ & Full plant & [50] \\
\hline & $\checkmark$ & - & $\checkmark$ & $\checkmark$ & - & $\checkmark$ & - & - & RO & Pilot scale & [51] \\
\hline & $\checkmark$ & - & - & - & - & - & - & - & $\mathrm{RO}$ & Full plant & [52] \\
\hline & $\checkmark$ & - & $\checkmark$ & - & - & - & - & - & RO & Full plant & [53] \\
\hline & $\checkmark$ & - & $\checkmark$ & - & - & - & - & - & $\mathrm{RO}$ & Pilot scale & [54] \\
\hline & $\checkmark$ & - & - & - & - & - & - & - & RO & Full plant & [55] \\
\hline & $\checkmark$ & - & - & - & - & - & - & - & RO & Lab scale & [56] \\
\hline & $\checkmark$ & $\checkmark$ & - & - & - & - & - & - & RO & Full plant & [18] \\
\hline & $\checkmark$ & $\checkmark$ & - & - & - & - & - & $\checkmark$ & MSF & lab scale & [57] \\
\hline & $\checkmark$ & - & $\checkmark$ & - & - & - & - & $\checkmark$ & $\mathrm{RO}$ & Full plant & [31] \\
\hline & $\checkmark$ & $\checkmark$ (Water preheating) & $\checkmark$ & - & - & - & - & - & $\mathrm{RO}$ & Lab scale & [58] \\
\hline & $\checkmark$ & - & $\checkmark$ & - & - & - & - & - & RO & Pilot scale & [59] \\
\hline & $\checkmark$ & - & $\checkmark$ & - & - & $\checkmark$ & - & - & $\mathrm{RO}$ & Full plant & [60] \\
\hline & - & $\checkmark$ & - & - & - & - & - & - & MED & Full plant & [61] \\
\hline & $\checkmark$ & - & $\checkmark$ & $\checkmark$ & - & $\checkmark$ & - & - & MED & Full plant & [62] \\
\hline & $\checkmark$ & $\checkmark$ & $\checkmark$ & - & - & - & - & - & RO and MED & Full plant & [5] \\
\hline Total number & 28 & 6 & 17 & 2 & 1 & 3 & 1 & 3 & & & 31 \\
\hline
\end{tabular}


Table 1. Cont.

\begin{tabular}{|c|c|c|c|c|c|c|c|c|c|c|c|}
\hline \multirow[t]{2}{*}{ Model Type } & \multicolumn{8}{|c|}{ Energy Resource } & \multirow[t]{2}{*}{$\begin{array}{l}\text { Desalination } \\
\text { Technology }\end{array}$} & \multirow[t]{2}{*}{ Scale } & \multirow[t]{2}{*}{ Ref. } \\
\hline & Solar electricity & Solar thermal & Wind turbine & Geothermal & Ocean energy & Hydro power & Diesel generator & Hydrogen & & & \\
\hline \multirow{30}{*}{ Off-grid } & $\checkmark$ & - & - & - & - & - & - & - & RO, Solar-still & Lab scale & [63] \\
\hline & - & - & - & - & $\checkmark$ & - & - & - & MED & Lab scale & [64] \\
\hline & $\checkmark$ & $\checkmark$ & $\checkmark$ & - & - & - & - & - & RO, MSF & Lab scale & [65] \\
\hline & $\checkmark$ & - & $\checkmark$ & - & - & - & - & $\checkmark$ & RO & Lab scale & [66] \\
\hline & $r$ & - & $\checkmark$ & - & - & - & - & - & $\mathrm{RO}$ & Lab scale & [67] \\
\hline & - & $\checkmark$ & - & - & - & - & - & - & MSF & Lab scale & [68] \\
\hline & $\checkmark$ & - & - & - & - & - & - & - & $\mathrm{RO}$ & Pilot scale & [69] \\
\hline & $\checkmark$ & - & - & - & - & - & - & $\checkmark$ & RO & Lab scale & [70] \\
\hline & $\checkmark$ & $\checkmark$ & - & - & - & - & $\checkmark$ & - & RO, MED & Lab scale & [71] \\
\hline & $\checkmark$ & - & - & - & - & - & - & - & ED & Full plant & [72] \\
\hline & - & - & - & - & $\checkmark$ & - & - & - & RO & Full plant & [73] \\
\hline & $\checkmark$ & - & - & - & - & - & - & - & $\mathrm{RO}$ & Pilot scale & [74] \\
\hline & - & $\checkmark$ & - & $\checkmark$ & - & - & - & - & MED & Pilot scale & [75] \\
\hline & $\checkmark$ & - & - & - & - & - & - & - & $\mathrm{RO}$ & Lab scale & [76] \\
\hline & $\checkmark$ & - & $\checkmark$ & - & - & - & - & - & RO & Pilot scale & [77] \\
\hline & $\checkmark$ & - & - & - & - & - & $\checkmark$ & $\checkmark$ & $\mathrm{RO}$ & Lab scale & [78] \\
\hline & $\checkmark$ & - & $\checkmark$ & - & - & - & - & - & RO & Pilot scale & [79] \\
\hline & $\checkmark$ & - & $\checkmark$ & - & - & - & - & - & RO & Pilot scale & [80] \\
\hline & $\checkmark$ & - & $\checkmark$ & - & - & - & - & - & $\mathrm{RO}$ & Pilot scale & [81] \\
\hline & $\checkmark$ & - & $\checkmark$ & - & - & - & - & - & $\mathrm{RO}, \mathrm{MD}$ & Pilot scale & [35] \\
\hline & $\checkmark$ & - & $\checkmark$ & - & $\checkmark$ & - & - & - & RO & Pilot scale & [82] \\
\hline & - & - & - & - & - & - & - & - & Solar-still & Full plant & [83] \\
\hline & $\checkmark$ & - & $\checkmark$ & - & - & - & - & - & RO & Full plant & [84] \\
\hline & $\checkmark$ & - & - & - & - & - & - & - & RO & Lab scale & [85] \\
\hline & - & $\checkmark$ & - & - & - & - & $\checkmark$ & - & MED, Solar-still & Lab scale & [86] \\
\hline & $\checkmark$ & - & - & - & - & - & - & - & RO & Full plant & [87] \\
\hline & $\checkmark$ & - & $\checkmark$ & - & - & - & $\checkmark$ & - & RO & Pilot scale & [88] \\
\hline & $\checkmark$ & - & $\checkmark$ & - & - & - & - & - & RO & Pilot scale & [89] \\
\hline & $\checkmark$ & - & $\checkmark$ & - & - & - & - & - & $\mathrm{RO}$ & Pilot scale & [90] \\
\hline & - & $\checkmark$ & - & - & - & - & - & - & MED & Full plant & [91] \\
\hline Total number & 23 & 6 & 13 & 1 & 3 & 0 & 4 & 3 & & & 30 \\
\hline \multirow[b]{2}{*}{$\begin{array}{l}\text { Number of studies/ } \\
\text { Total studies }\end{array}$} & On-grid & Off-grid & RO & MED & MSF & Solar still & lab scale & Pilot scale & Full plant & & \\
\hline & $30 / 60$ & $30 / 60$ & $56 / 60$ & $9 / 60$ & $3 / 60$ & $3 / 60$ & $15 / 60$ & $23 / 60$ & $22 / 60$ & & \\
\hline
\end{tabular}




\subsection{System Configuration}

Conventional thermal desalination technologies are now well-proven and mature. Therefore, a further improvement in these technologies is relatively limited. Continuous innovation in RO desalination technology in the last twenty years has reduced the energy consumption per unit of product water to $1.8 \mathrm{KWh} / \mathrm{m}^{3}$ compared to the historic energy consumption range of 3 to $5.5 \mathrm{KWh} / \mathrm{m}^{3}$, which is close to the theoretical minimum required energy for seawater desalination [92]. This means that a further significant reduction in energy consumption is not expected for RO technology. However, further significant advances in membrane technology (increasing in water productivity per area) are predicted, which could cause up to a 20 percent cost reduction in the next five years [4].

In Table 2, the production capacity of desalination units is divided into three levels by scale: small (less than $20,000 \mathrm{~m}^{3} /$ day), large (between $20,000 \mathrm{~m}^{3} /$ day to $200,000 \mathrm{~m}^{3} /$ day), and mega (more than $200,000 \mathrm{~m}^{3} /$ day).

Table 2. Brief configuration of water-energy systems.

\begin{tabular}{|c|c|c|c|c|c|}
\hline \multicolumn{2}{|l|}{ Energy Sector Description } & \multicolumn{2}{|l|}{ Water Sector Description } & \multirow[t]{2}{*}{ Type of Analysis } & \multirow[t]{2}{*}{ Ref. } \\
\hline Model Type & Energy Type & Application & Scale & & \\
\hline \multirow[t]{32}{*}{ Centralized } & Electricity & Potable & Small & Theoretical & [49] \\
\hline & Electricity & Potable & Small & Theoretical & [43] \\
\hline & Electricity & Potable and Agriculture & Small & Experimental & [56] \\
\hline & Electricity & Potable & Large & Theoretical & [36] \\
\hline & Electricity & Potable & Large & Experimental & [50] \\
\hline & Electricity & Potable & Large & Theoretical & [38] \\
\hline & Electricity & Potable & Small & Theoretical & [45] \\
\hline & Electricity & Potable & Large & Theoretical & [46] \\
\hline & Electricity & Potable & Large & Theoretical & [18] \\
\hline & Electricity & Potable & Large & Theoretical & [39] \\
\hline & Electricity and thermal & Potable & Large & Theoretical & [57] \\
\hline & Electricity & Potable & Large & Theoretical & [84] \\
\hline & Electricity & Potable & Large & Theoretical & [31] \\
\hline & Electricity & Potable & Small & Theoretical & [74] \\
\hline & Electricity & Potable & Small & Theoretical & [47] \\
\hline & Electricity and thermal & Potable & Large & Theoretical & [58] \\
\hline & Electricity & Potable & Small & Experimental & [85] \\
\hline & Electricity & Overall & Large & Theoretical & [93] \\
\hline & Electricity & Potable & Large & Theoretical & [59] \\
\hline & Electricity & Potable & Small to Large & Theoretical & [48] \\
\hline & Thermal & Potable & Small & Experimental & [48] \\
\hline & Thermal & Agriculture & Large & Pilot-project & [91] \\
\hline & Electricity & Potable & Large & Theoretical & [40] \\
\hline & Electricity & Potable & Large & Theoretical & [60] \\
\hline & Thermal & Potable & Large & Theoretical & [61] \\
\hline & Electricity & Potable & Large & Theoretical & [41] \\
\hline & Electricity and thermal & Potable & Laboratory scale & Experimental & [65] \\
\hline & Electricity & Potable & Large & Theoretical & [52] \\
\hline & Electricity & Potable & Small & Theoretical & [79] \\
\hline & Electricity & Potable & Small & Theoretical & [42] \\
\hline & Electricity & Potable & Small & Theoretical & [82] \\
\hline & Electricity and thermal & Overall & Mega & Theoretical & [94] \\
\hline \multirow{12}{*}{ Decentralized } & Electricity & Potable & Small & Theoretical & {$[63]$} \\
\hline & Electricity & Agriculture and Potable & Small & Theoretical & [73] \\
\hline & Solar-stills & Agriculture & Small & Theoretical & [83] \\
\hline & Electricity & Potable & Small & Theoretical & [87] \\
\hline & Electricity & Potable & Small & Theoretical & [67] \\
\hline & Electricity & Potable & Small & Theoretical & [89] \\
\hline & Electricity & Potable & Small & Theoretical & [80] \\
\hline & Electricity & Potable & Small & Theoretical & [69] \\
\hline & Electricity & Potable & Small & Theoretical & [81] \\
\hline & Electricity & Agriculture & Small & Theoretical & [70] \\
\hline & Electricity & Potable & Small & Experimental & [35] \\
\hline & Electricity & Potable & Small to large & Theoretical & [55] \\
\hline Decentralized and Centralized & Electricity and thermal & Potable & Small to large & Theoretical & {$[5]$} \\
\hline \multirow{2}{*}{$\begin{array}{l}\text { Number of studies/ } \\
\text { Total studies }\end{array}$} & Thermal & Agriculture & Small & Experimental & \\
\hline & $8 / 45$ & $7 / 45$ & $25 / 45$ & $7 / 45$ & \\
\hline
\end{tabular}


A centralized water system refers to systems in which desalinated water is produced in one unit and distributed among all target users, while a distributed water system includes more than one desalination unit that is providing water demands. These decentralized desalination plants (mostly small-scale) have a great potential to solve the intermittent power generation problem of variable renewable resources (namely, wind and solar). These desalination plants can effectively operate without energy storage systems (mostly batteries), as water can be desalinated based on energy availability and stored as the final product [95]. This direct consumption of renewable energy increases the efficiency of the whole system because storage systems such as battery systems have a typical charge-cycle efficiency of $75 \%$ to $98 \%$ [5]. Furthermore, high ambiance temperatures, which are common in regions facing water scarcity, increase the self-discharge rate and performance of batteries. A small-scale RO desalination unit coupled with a PV system with battery storage in Malaysia was tested for six months [85]. This experiment aimed to examine the system performance and find the optimal condition to operate an RO desalination unit. The results indicated that climatic conditions (such as high ambiance temperatures) significantly reduced the performance of the battery and PV system.

Although desalination units with larger capacity face technical limitations to operate as variable units, it is still possible to integrate them with renewable resources to a certain extent [94]. For instance, one of the main problems with an intermittent RO desalination unit is the biological fouling when the unit is not in operation. The pretreatment of intake feed-water can significantly decrease the fouling [29]. This membrane fouling needs to be considered in the desalination system design in order to avoid an under-sized system and unmet water demand [96].

Flexible load resources can support ancillary services in electric grids. In this regard, the key operating features to determine the adequacy of the flexible loads are as follows [59]:

- Initial response time: the response duration time to a change in a power set-point.

- Ramp rate: the change rate of power consumption.

- Settling time: the settle time duration after an operating power set-point change.

- Duration: the period after settling time required to maintain the settled changed power set-point.

- Power capacity: the rated power points for operating the flexible load resources, which vary from kilowatts to megawatts.

- Minimum turn-down: the lowest operating point of the flexible load, below which the flexible load resource must be turned off.

According to the above criteria, desalination is perceived as an attractive option to integrate with renewable energy resources as a flexibleelectric load. As an example, the minimum turn-down for RO desalination plants is unlimited. The authors in [59] tested the capability of an RO desalination plant to manage the variability of renewable energy production while supporting (1) the above mentioned ancillary services in an electric grid and (2) meeting water demand with the desired quality level. The results of this study showed that RO desalination plants are capable of responding quickly, settling fast and operating long enough at required power points while maintaining the desired water demand quantity and quality. The authors in one study [97] showed the potential of an MED plant for the peak shaving of a coal-fired power plant.

The levelized cost of energy in a 100 percent renewable energy scenario for Saudi Arabia decreased by 3 percent by integrating the desalination sector with the energy system in study [39]. The required battery storage was reduced because of the flexibility provided by RO desalination plants. The authors in another study [57] introduced an integrated process of MSF desalination, hydrogen production, and solar power production. This study considered solar hydrogen production as an energy storage and a hydrogen-fired power plant to overcome issues related to the intermittency of solar power generation. Furthermore, a centralized water system typically requires more energy for the water transfer and distribution than a decentralized water system. Water distribution pumps, with $70-80 \%$ of the energy consumed in a surface-water-based supply, are the highest energy-intensive components of conventional water supply systems [28]. 
As can be seen in Table 2, the number of studies that investigated the centralized water system and the decentralized water system are very few. Study [5] developed a novel methodology for the sustainable planning of energy and water supplies with a share of renewables and desalination. This study conducted a comprehensive comparison between centralized and decentralized desalination systems and their technical, economic and environmental impacts on the energy and water sectors. This study found that a decentralized water sector and renewable-powered MED disalination technology experienced synergistic benefits and avoided conflicts between the water and energy sectors in the Middle East. Researches have studied [55] an alternative water system to meet water demand in a region of Australia. This study first calculated the capacity and surplus of rooftop PV systems in this region through a spatial model. In the next step, based on solar power production and surplus, a distributed water system was optimized, producing water through the RO process. This distributed water desalination system leads to a decrease of around 10 percent in the levelized cost of water and about 20 percent decrease in the levelized cost of solar energy compared to a centralized water desalination system for this region.

\section{Economic Aspect}

Removing the salts from saline water is a high-cost and high energy-consuming process compared to other freshwater supply and treatment alternatives. This section discusses the prospects of the current desalination costs and expected future costs of desalination for different technologies. Desalination technology, plant size, feed-water (salinity, temperature, and biofouling elements), energy use, intake-outlet system (environmental regulations), and target water quality (municipal, industry, or agriculture use) are the main factors affecting the desalinated water costs. Table 3 summarizes the cost of desalination for current commercially viable desalination technologies. The authors in [93] developed a model to estimate the cost of providing municipal, industrial, and agricultural water demand using RO desalination plants powered by a combination of PV, wind energy, battery and power-to-gas plants for regions facing water scarcity (regions where more than 40 percent of the renewable water resources are being withdrawn) in 2030. The levelized cost of water (LCOW) for the described system was found to be 0.65 to $3.10 \mathrm{USD} / \mathrm{m}^{3}$. Table 4 gives an overview of the current situation and the pros and cons of desalination technologies.

Table 3. Cost components of the dominated desalination technologies [4,9].

\begin{tabular}{|c|c|c|c|c|c|c|c|c|}
\hline Technology & $\begin{array}{l}\text { Total Cost } \\
\text { USD } / \mathrm{m}^{3}\end{array}$ & $\begin{array}{c}\text { Amortised Capital } \\
(\%)\end{array}$ & $\begin{array}{l}\text { Electrical Energy } \\
(\%)\end{array}$ & $\begin{array}{c}\text { Thermal Energy } \\
(\%)\end{array}$ & $\begin{array}{c}\text { Membranes } \\
(\%)\end{array}$ & $\begin{array}{l}\text { Labor } \\
(\%)\end{array}$ & $\begin{array}{c}\text { Chemicals } \\
(\%)\end{array}$ & $\begin{array}{c}\text { Miscellaneous } \\
(\%)\end{array}$ \\
\hline RO & $0.6-2.86$ & 38.2 & 31.6 & - & 3.9 & 13.2 & 9.2 & 3.9 \\
\hline MED & $1.12-1.5$ & 34.9 & 7.2 & 37.3 & - & 9.6 & 9.6 & 1.2 \\
\hline
\end{tabular}

Table 4. Energy consumption of desalination technologies [4,9,23,94,98-102]. H/DH: humidification/dehumidification; VC: vapor compression; ED: electrodialysis; MD: membrane distillation.

\begin{tabular}{|c|c|c|c|c|c|c|c|c|}
\hline Technology & H/DH & MSF & MED & VC & RO & FD & ED & MD \\
\hline $\begin{array}{l}\text { Thermal energy } \\
\mathrm{KWh} / \mathrm{m}^{3}\end{array}$ & 45-100 & $7.5-11$ & $4-7$ & $\begin{array}{l}0 \text { (MVC) } \\
51.9-63 \text { (TVC) }\end{array}$ & - & $8-24$ & - & $30-240$ \\
\hline $\begin{array}{l}\text { Electricity } \\
\mathrm{KWh} / \mathrm{m}^{3}\end{array}$ & - & $2.5-3.5$ & $1.5-2.5$ & $\begin{array}{l}7-15 \text { (MVC) } \\
1.6-1.80 \text { (TVC) }\end{array}$ & $1.8-6$ & - & $2.46-5.5$ & $0.6-1.8$ \\
\hline
\end{tabular}

\subsection{Desalination Technology and Plant Size}

It has been found that the capital costs and operating costs of desalination technologies are nonlinear functions of their capacity [103]. By reviewing and analyzing data, a study [103] found different degrees of non-linearity and types of correlations for each desalination technology. The capital cost of thermal desalination plants is about 1.50 to 2.00 million USD/MLD (where MLD refers to million 
Liter/day), which is higher than the capital cost for RO plants with about 1.3 million USD/MLD. Construction cost accounts for around 75 percent of the capital cost of thermal desalination units, while it is about 50 percent for $\mathrm{RO}$ plants. By contrast, $\mathrm{RO}$ desalination plants are more design-intensive (cost of engineering services, skilled labor, regulatory and etc.) and thermal desalination units require heavier physical investment due to higher technology maturity.

According to studies, the total cost of producing freshwater with MSF plants is between 1.02 and $1.74 \mathrm{USD} / \mathrm{m}^{3}$. The total cost of water production, including capital cost and O\&M costs, is reducing proportional to the plant size. For medium-size (between 20,000 to 100,000 $\mathrm{m}^{3} /$ day) MSF plants, the cost of water production is about 1.50 to $1.74 \mathrm{USD} / \mathrm{m}^{3}$, while for large plants this cost is about $1 \mathrm{USD} / \mathrm{m}^{3}$. Even though the total energy cost for the MSF process is higher than the energy cost for the RO process, the total cost of MSF water desalination is competitive to medium- and large-sized RO plants. Co-locating MSF plants with power plants lowers the steam cost, which is a requirement for this technology, and keeps the cost down for this technology. Besides, unlike RO product water, the water product of MSF technology is of immediate potable quality. It is noteworthy to mention that innovations in this technology have been limited recently, impacting costs slightly.

The total cost of freshwater production for MED technology is between 1.12 and $1.5 \mathrm{USD} / \mathrm{m}^{3}$. Medium-scale MED facilities (between 20,000 to 100,000 $\mathrm{m}^{3}$ /day) are producing water at a lower cost than MSF plants with the same size due to lower capital and O\&M costs. Although for small-scale (less than 20,000 $\mathrm{m}^{3} /$ day) and medium-sized plants, MED units are more energy efficient with cost advantages, MSF plants are easier to operate, which sometimes makes them the preferred option for investors due to lower risk. At larger facility sizes, the water produced by MSF technology is cheaper than MED water production.

For RO desalination facilities, the cost of water production varies between 0.6 and $2.86 \mathrm{USD} / \mathrm{m}^{3}$. RO desalination plants have a significant cost advantage for small-scale (below 20,000 $\mathrm{m}^{3} /$ day) and medium-scale facilities compared to other desalination technologies. Moreover, further significant advances in membrane technology (increasing in water productivity per area) are predicted to cause an up to 20 percent cost reduction in the next five years [100] (see Table 5).

Table 5. Forecast of RO membrane productivity and costs [103].

\begin{tabular}{lccc}
\hline Parameters & 2016 & Within 5 Years & Within 20 Years \\
\hline Cost of product water $\left(\mathrm{USD} / \mathrm{m}^{3}\right)$ & $0.8-3$ & $0.6-1.0$ & $0.3-0.5$ \\
Electricity requirement $\left(\mathrm{KWh} / \mathrm{m}^{3}\right)$ & $3-4$ & $1.8-3.2$ & $1.1-2.4$ \\
Membrane productivity $\left(\mathrm{m}^{3} / \mathrm{membrane}^{2}\right)$ & $28-47$ & $35-55$ & $95-120$ \\
\hline
\end{tabular}

\subsection{Feed-Water}

Salinity, temperature and biofouling elements of feed-water are important factors for RO desalination efficiency, performance, and costs, while the thermal desalination process is mostly insensitive to these factors. For low salinity, $\mathrm{RO}$ units desalinate water with lower cost comparing to the thermal desalination technologies, mainly because of energy-saving and lower energy requirements. As an example, a Red Sea RO seawater desalination plant with an average salinity of TDS (total dissolved solids) 44 ppt requires 30 percent more energy comparing to plants desalinating Pacific Ocean or Atlantic Ocean seawater, which have a salinity of TDS 46 ppt, with all other conditions being the same [4].

Changes in feed-water quality and temperature affect the efficiency of RO plants because the membrane performance is sensitive to these changes during the thermal desalination process. Study [100] found that RO plants in the Persian Gulf require 16 percent more capital costs and 14 percent more recurrent costs compared to ones in the Mediterranean region because of the different source of water. This is mostly because of the higher salinity and biofouling potential of seawater in the Persian Gulf, which requires costly pretreatment and intake systems and a more frequent need to change or clean the membranes. 


\subsection{Target Product Water Quality}

Target water demands in the current study are categorized into three groups (see Table 2), namely potable demand, industrial demand, and agriculture demand. Table 2 illustrates that studies in this field have mostly targeted potable water, and there are few studies which studied the agricultural or industrial sectors as the target water user.

The product water of the thermal desalination process has lower salt (TDS of 50 milligrams per liter), boron, and bromide levels compared to water desalinated through the RO process. The high level of salt and boron of desalinated RO water needs to pass through an additional RO stage to achieve good-quality water. The second-pass stage can increase by 10 to 25 percent in the total cost of the first-pass desalination process [4]. Furthermore, calcium-based compounds and chlorine (for disinfection) are added to desalinated water (which is typically soft) before distribution. For most of the industrial and agricultural applications, it is not necessary to design this second-pass stage. The current costs of $\mathrm{RO}$ product water of desalination include the second-pass stage, which can reach up to 25 percent of the total $\mathrm{RO}$ water desalination costs and there is a lack of study in evaluating RO units without this second-pass stage.

\subsection{Energy}

Energy is the most important factor affecting the extent and feasibility of desalination; from $30 \%$ to over $50 \%$ of the cost of water produced by desalination processes is related to energy (see Table 3). Energy affects not only the cost of water produced by desalination but also the technology of the desalination process. For example, to use thermal processes, the largest desalination plants are located in the Middle East regions, which have rich fossil fuel reserves [23]. Total recurrent costs for each unit product of RO desalination plants are about twice those of MSF desalination plants and three times more than the MED per unit of water production. The main share of this recurrent costs goes to energy.

Study [49] designed an energy supply for an RO plant to desalinate brackish water in a rural area in Australia. The RO desalination unit with variable capacity operation has been assumed to treat brackish water of a river as a water supply. The optimization results for a 25 -year period showed that the hybrid system with a combination of wind turbines, rooftop solar photovoltaic and electricity grid had the minimum levelized cost of energy (COE) and minimum overall net present cost (NPC). However, the operation and maintenance cost of the desalination plant and the required energy for the water distribution system were considered in this model.

Another study [104] investigated several scenarios to achieve a net zero-emissions electricity supply system by 2050. In two scenarios, the future electricity demand for seawater desalination was forecast and considered. Although desalination demand was approximately 3 percent of the total electricity demand in 2050, the comparison among scenarios showed that sector coupling between the desalination and electricity sector does not cause a significant change to the future electricity supply. The reason is that the desalination electricity demand was constant in this study, causing the electricity system to extract no benefit from using desalination plants as flexible electric loads to compensate for the fluctuation of variable renewable power production. The authors in [94], by considering desalination units as flexible loads, found that the levelized cost of energy is 30 percent lower than the cost with desalination as non-flexible loads due to less required battery storage to compensate for the fluctuation of wind and photovoltaic electricity production in Iran.

The authors in another study [105] evaluated the overall costs of RO water desalination by considering several scenarios for energy supplies in Chile. This study divided these costs into two categories, including internal costs and external costs. Internal costs refer to investment costs as well as operation and maintenance costs, while the external costs cover a carbon tax on energy resources. The evaluation in this study showed that by considering this carbon tax, the unit cost of desalinated water for scenarios with renewable energy resources is lower than the scenarios powered by conventional energy resources. 
Water distribution pumps are energy-intensive components, which should be considered for site selection, size of desalination plants, and type of water system (distributed water system with several small-size desalination units or centralized water systems with a large-size desalination unit). Water transport costs from coastal desalination plants are estimated in other studies $[9,106]$. Table $6[5]$ shows the cost of desalinated water transfer in several countries. The cost of water transfer in some cases in this table is considerable compared to desalinated water costs. Figure 3 depicts the current state of development, potential capacity and estimated cost of water production for the integration of renewable energy resources with desalination technologies. For details, see the list of the reference studies to outline the development state of renewable-powered desalination technologies in [5].

Table 6. Transport costs of desalinated water ([5]).

\begin{tabular}{lccc}
\hline City, Country & $\begin{array}{c}\text { Distance } \\
(\mathbf{k m})\end{array}$ & $\begin{array}{c}\text { Elevation } \\
(\mathbf{m})\end{array}$ & $\begin{array}{c}\text { Transport Cost } \\
\left(\mathbf{U S D} / \mathbf{m}^{\mathbf{3}}\right)\end{array}$ \\
\hline Beijing, China & 135 & 100 & 1.1 \\
Mexico City, Mexico & 225 & 2500 & 2.4 \\
Yemen, Sana & 135 & 2500 & 2.2 \\
Mexico City, Mexico & 280 & 320 & 2.4 \\
Crateus, Brazil & 240 & 350 & 1.3 \\
Zaragoza, Spain & 163 & 500 & 1.4 \\
Riyadh, Saudi Arabia & 350 & 750 & 1.6 \\
New Delhi, India & 1050 & 500 & 1.9 \\
\hline
\end{tabular}

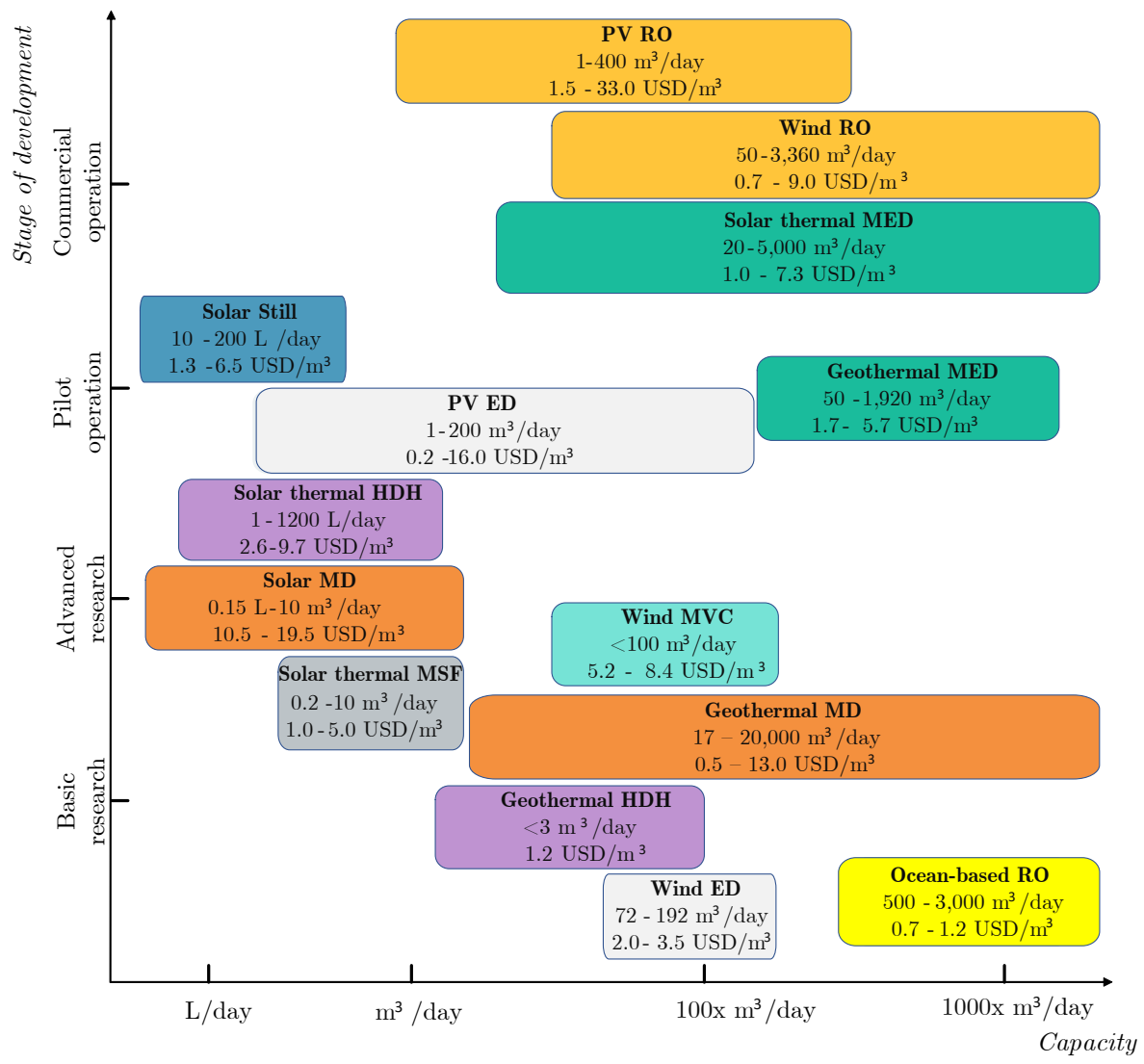

Figure 3. The status of the renewable energy operated desalination technologies (adapted from [5]).

The current share of renewable desalination is less than 1 percent of global desalination capacity [107]. The cost of renewable desalination is still higher than the cost of conventional desalination powered by fossil fuels. However, renewable technologies are experiencing a rapid 
cost reduction, making the renewable desalination already cost-competitive with the conventional desalination in remote regions (where the cost of electricity transmission and distribution is higher than the cost of decentralized electricity production). With this rapid cost reduction of renewable technologies, technical advances, and an improvement in the knowledge and experience by increasing the number of installations, the costs of renewable-powered desalination are likely to reduce significantly in the near future. It is expected that a major portion of fossil-fuel-powered desalination plants will be replaced by renewable-powered desalination with an average cost of $0.9 \mathrm{USD} / \mathrm{m}^{3}$ by 2050 [108]. The renewable desalination was forecast to be sufficient only for domestic water supply in 2030, but to expand for further domestic and industrial water supply needs by $2050[108,109]$.

As discussed, each desalination technology has its advantages and disadvantages. As shown in Table 1, RO is the most utilized desalination technology among previous studies indicating the potential of this technology for integration with renewables as a future sustainable solution for water-scarce regions. As an advantage, $\mathrm{RO}$ plants are scalable, typically consisting of several dozen units, and thereby its size can be expanded to meet the growing demand by adding more units as needed. The costs of RO desalination significantly decrease in treating lower salinity or brackish water due to lower energy requirements. By contrast, thermal distillation processes, namely MED and MSF technologies, need the same amount of energy regardless of salinity. As a result, thermal distillation processes are more competitive than $\mathrm{RO}$ desalination technology for high salinity waters when there is also high biofouling potential. MED technology is more competitive at a smaller scale compared to MSF technology, making this technology a better option for integration with renewables. Furthermore, MED operates at lower temperatures than MSF; as a result, its process is more compatible for integrating with renewable thermal power generation.

Solar and wind resources have been widely used for powering desalination among previous studies (see Table 1). Power generation from wind and photovoltaic requires zero or little water use [107]. Wind power is likely to be cheaper than photovoltaic power wherever it is available. Coastal areas usually benefit from a high availability of wind power resources. On the other hand, water-scarce regions or drylands are characterized by abundant solar radiation, which increases the capacity factor of solar resources and makes them more competitive compared to wind resources [110].

To sum up, the most promising combination of technologies is RO desalination technology with photovoltaic and MED desalination technology with solar thermal collectors. For large-scale units, wind power is more attractive wherever it is available, as it does not need a large area for installation, such as islands where often limited flat ground is available.

\section{Environmental Aspect}

Studies repeatedly addressed the two major environmental impacts of the desalination process, which are high carbon footprint due to energy consumption (indirect impacts) and intake seawater and effluent-associated pollution (direct impact). Thermal, chemical and saline pollution caused by the disposal of concentrate from the desalination process, which is most commonly discharged to the ocean, are the main environmental impacts of desalination. Evidently, the magnitude of these environmental impacts depends on the choice of desalination technology and site.

One study [63] compared three systems to provide potable water for a rural area in the UAE based on environmental impacts. These water systems included a solar still unit, a PV system coupled with an RO unit, and water delivery by truck from a central RO plant. The environmental impacts in this study were categorized as eco-toxicity, minerals, fossil fuels, carcinogens, respiratory inorganics, radiation, ozone layer depletion, acidification/eutrophication, respiratory organics, climate change, and land use. The result of a life cycle assessment indicated that the PV system, coupled with the RO unit, had the smallest environmental impact among these three proposed options. 


\subsection{Intake-Related Environmental Impacts}

The main impact of intake facilities is on aquatic organisms. Subsurface intake wells (instead of direct saline or brackish water intake from the surface water) and constructed wetlands are commonly used to mitigate the environmental impacts of seawater intake for desalination. Adding an intake impact mitigation stage to desalination units can increase the capital cost by 5.3 percent and the annual O\&M costs by 4.5 percent [111]. The authors in another study [36] assessed the environmental impacts of the open-intake pretreatment and subsurface intake pretreatment of two RO desalination plants in the Persian Gulf. A life cycle assessment highlighted that the subsurface intake method had fewer environmental impacts compared to open intake pretreatment.

As discussed, renewable-powered desalination is suitable for the distributed or decentralized water sector because of its size compatibility. The decentralized system increases the options of site locations for desalination units. Such multiple options enable the policymakers to choose site locations with a lower density of aquatic organisms.

\subsection{Effluent-Related Environmental Impacts}

Brine is a sub-product of the desalination process causing two environmental impacts including the effects of highly concentrated saline solution and metal components (copper, nickel, iron, chromium, zinc, etc., which are discharged with the brine during pre- and post-treatment processes [112]) that may heavily affect marine ecosystems. Besides, the outlet brine of the thermal desalination process could have a higher temperature than the ambient seawater and the amount of brine volume is much greater than the volume from RO process (thermal desalination technologies use almost twice as much saline water comparing to RO technology to produce the same amount of freshwater). On the other hand, the outlet from the RO process is more concentrated, which requires treatment prior to discharge.

To decrease the impacts of brine on marine ecosystems, first, the discharging of brine into sensitive ecosystems must be avoided through process design (technology, unit size, etc.) and the assessment of site location (site ecological value, hydro-geological and hydrodynamic conditions, etc.); second, the salinity must be reduced through active dilution processes, such as artificial diffusers or through natural local hydrodynamic conditions. Another study [113] introduced a geographic information systems multi-criteria framework to identify regions that where suitable for the deployment of RO units coupled with solar energy supplies. This study chose solar irradiance, ocean salinity, ocean temperature water stress, prevailing water prices, and population as factors for evaluation. Another study [73] examined the potential of wave energy resources to provide the power demand of current desalination plants for an island in Spain. This study investigated the selected location based on the environmental lens to assure that there is no vulnerable or sensitive area (such as reserves or marine and land habitats, with some environmental protection), which are leading to restrictions for the deployment of wave energy converters. The technical aspect and the compatibility of the desalination technologies with the proposed alternative energy resource were not considered in this research.

According to [23], adding ocean salinity gradient energy devices (e.g., PRO, FO, and RED) to existing desalination plants can decrease these environmental and social risks without a major change to current desalination infrastructures. Another study [30] introduced a hydro storage system with a reverse osmosis desalination plant that can help the problems related to brine disposal of reverse osmosis plants by diluting with seawater before releasing to sea. However, this study did not consider environmental issues due to an artificial lake with brine water, which has vast consequences for each ecology. For instance, the area proposed for usage as a lake for pumped hydro storage around the capital of Iran, Tehran, is located in important agricultural lands.

Another study [114] investigated the current status of regulations on discharge from desalination plants in Saudi Arabia. The results indicated that studies regarding the discharge from desalination plants are facing deficient statistics and a lack of supporting data. This study showed the necessity to impose more strict regulations on effluent water quality monitoring systems in desalination plants. 


\subsection{GHG Emissions of the Desalination Process}

Powering desalination processes with renewable energy resources is considered the main solution to decrease the GHG emissions of desalination plants. It is noteworthy to mention that different renewable resources also have different levels of GHG emissions that need to be considered in studies. The authors in one study [115] provided an estimation about the potential reduction of life cycle GHG emissions of RO, MED, and MSF technologies when renewable energy supplies were utilized instead of conventional energy systems. This study showed that hydro-power has the best performance in decreasing GHG emissions compared to wind and solar supplies. In this study, desalination units were considered as fixed loads and the fluctuation of renewable power was neglected, which is not realistic.

Cities are aiming to increase the share of local water resources for enhancing water security, but the GHG footprint of these local sources should be compared to imported sources to reach solutions that are more effective. Including upstream (non-combustion) emissions of energy resources is another aspect that should be considered in models to achieve more holistic results. By excluding upstream emissions in a study [116], the carbon footprint of water supplies in Southern California were shown to be underestimated by up to 30 percent. The results of this study indicated that with current energy supplies in Southern California, importing water caused a lower carbon footprint than expanding local recycled water.

Another study [117] proposed an urban water system to apply several scenarios for the water sector for a city in Canada. The difference between scenarios included considering wastewater as a water resource and demand-side water management. This study calculated the amount of energy consumption related to the water sector, the water consumption of the energy sector and the $\mathrm{CO}_{2}$ emissions related to the water sector due to energy usage for each scenario. This study concluded that designing these policies, scenarios, and plans (such as carbon mitigation) should not discourage economic or population growth. For reaching this aim, the most important step is the baseline measurements, which should be calculated based on alternative metrics, for example, emissions per GDP or per jobs.

\section{Social Aspects}

Palestine and its neighbor counties have access to the Mediterranean Sea, facing land limitations for developing large-scale renewable energy projects. Meanwhile, Jordan (a neighbor country) has an abundance of available land suitable for solar electricity production but has no access to the Mediterranean Sea, which is close to population areas facing water scarcity in Jordan. The authors of [46] examined the technical and economic feasibility of exchanging desalinated water with renewable electricity among countries. This study considered the exchange of desalinated water and RE as a potential solution to improve the relationship among these countries, which are facing critical political issues. Social acceptance has a vital role in the failure or success of such projects. For instance, according to a study [49], an RO desalination project was opposed and halted in Australia as a result of the lack of community engagement during the planning and the common perception of the $\mathrm{RO}$ as an environmentally unsustainable and energy-intensive solution. The study showed that increasing renewable energy resources in this region could improve the social acceptance of the desalination project. Deploying desalination units could have significant social impacts on society during the construction and operational stages. Social impacts of desalination units include lack of public trust and confidence in water supply, issues related to dust, noise and visual facilities, disturbance of the beach and sea-based recreational activities, pipelines, and the future residential and industrial development in the local area.

The authors in [45] studied two approaches to decide about desalination technology ( $\mathrm{RO}$ and MVC) and source of energy (wind turbine or PV) for a desalination unit in an island in Italy. In the first approach, just the technical and economic feasibility were investigated, as a result of which the combination of RO technology with wind energy had the best performance. The list of considered criteria in the second approach included economic, environmental, social, legislation, policies, and 
technical aspects, as well as the specific location characteristics. Through a multi-criteria analysis with the participation of stakeholders, the combination of RO technology and PV ranked highest using the second approach. A survey with 333 respondents was conducted in Australia [9], with around 55 percent of respondents having very low to low levels of trust in the desalination water corporation, while 23 percent of them neither trusted nor distrusted the company. Social issues of desalination also depend on the size of the community. Desalination technologies might face fewer issues with large communities. A study [118] focused on the social acceptance of small-scale RO plants with solar electricity supply in remote areas in Central Australia. This study evaluated the unit's capacity to meet water demands (potable, non-potable domestic, and agriculture demand), the human resources availability to operate and maintain these units, and the attitudes of community members to prototype RO units. The results of interviews, questionnaires, and site visits indicated that these units were generally perceived positively, showing great potential for acceptance by communities. One of the best examples to depict the role of public acceptance is the case of Ngare Nanyuki in Northern Tanzania. Volcanoes in nearby mountains are the potable water supply for this area, which was considered as a symbol of pure water by their society. These natural water resources contain high levels of fluoride, which is toxic. Although a membrane-based desalination unit is producing high quality and healthy water for this region, people are still drinking directly from the toxic water sources [29].

\subsection{Role of Culture}

The massive deployment of desalination technologies in a society can trigger a cultural change in water consumption. Although water scarcity has accelerated recently, it is not a new phenomenon and in arid parts of the world watering techniques have been adapted to this resource-scarce condition for centuries. Another study [119] refers to the fact that the rise of water consumption in Lanzarote, Morocco, after the introduction of desalination technologies was a result of falling costs of supply and water availability rather than an increase in actual water demand. Hence, countries considering desalination units as their future water supply need to focus on the demand side to conserve traditional, water-saving consciousness developed by the local population and increase the awareness of society regarding the amount of energy and materials that are consumed in the desalination processes. As another example, a community in Greece destroyed solar stills, which were donated [29]. This example reveals that society needs to pay for a share of service costs, even if partially, to increase society's responsibility towards that service.

Another study [120] discussed the sustainable solutions to meeting future water demand in the UAE, including increasing the efficiency of the water sector and diversifying the water supplies (applying wastewater treatment and solar RO plants). Based on this article, treated wastewater is not a viable source for the domestic sector in Islamic countries due to religious beliefs.

\subsection{Policy-Making}

Decision-makers should consider both the demand side and the supply side to reach more effective roadmaps in the water sector. A study [121] compared the results of different water trajectories for two regions in Australia including South East Queensland and Perth between 2002 and 2014. Both areas encountered a water crisis for some time during this period. The decisions in Perth have been focused on the supply-side, while in South East Queensland, in addition to the supply side, demand-side management was considered in decisions. Another study [122] proposed a framework to evaluate the policies in the water and energy sectors to develop concentrated solar thermal technologies coupled with desalination technologies in South Africa. This study aimed to assist policy-makers in truly understanding the nexus and complexity of the water and energy systems they are attempting to influence. The size of the community also affects the social issues of desalination technologies. The authors in [9] discussed small communities in remote locations as an example. These locations usually rely on transported water and water supply infrastructure does not exist; in consequence, desalination projects face lesser social issues compared to locations with 
large communities, and in addition, these projects might seem attractive for them. The authors in another study [123] studied policies and legislation within the European Union in the Mediterranean region for developing autonomous desalination units powered by renewables. Policy barriers to decentralized desalination implementation generally stemmed from ignorance regarding these systems when desalination regulations were enacted. These decentralized systems were viewed as large fossil-fuel-based desalination systems with outright opposition in the regulations. As an example, small-scale water abstractions in the region were exempt from both the Water Framework Directive and the Drinking Water Standards Directive, while the decentralized autonomous desalination systems had to comply with strict regulations that apply to all drinking water supplies. Another study done in Turkey [124] indicated that the framework conditions in this country do not pose unnecessary barriers for the implementation of autonomous desalination units.

The authors of [125] first investigated the current and future status of the Jordanian water and energy sectors and then focused on linkages between these sectors. In the next step, this study addressed the stakeholders of both sectors and the solutions to enforce the links between these two sectors in Jordan's future policy-making. The study classified the stakeholders based on power, legitimacy, and urgency and provided solutions to increase the inter-linkages between key actors and groups for achieving sustainable integrated water and energy policy-making. According to Jordan's future energy plan, oil shale and nuclear energy are expected to increase from zero to $21 \%$ of total energy supply by 2022. The required water intensity of oil shale extraction is significantly larger than that for conventional oil extraction. Due to insufficient groundwater and surface water resources in the country, seawater desalination and reuse of municipal sewage are the only alternatives.

Water pricing policies need to consider the social and environmental elements above the technical aspect. Heavily subsidized prices can induce changes in user behavior and cause an unexpected increase in irresponsible utilization and inefficient resource use by ignoring the demand-side behavior in policy-making [9]. 
Table 7. Summary of focal factors in desalination systems powered by renewable resources.

\begin{tabular}{|c|c|c|c|c|c|c|c|}
\hline Horizon & Description of the System & Nexus & Approach & Analysis & Uncertainty Level & Geographical Scale & Ref. \\
\hline \multirow[t]{9}{*}{$\begin{array}{l}\text { Review/ } \\
\text { Understanding }\end{array}$} & $\begin{array}{l}\text { - Applying ocean-based energy generation as an energy } \\
\text { resource for desalination plant }\end{array}$ & Technical and Environmental & Optimization & Qualitative & - & - & [23] \\
\hline & - Sustainable solutions to meet future water demand in the UAE & Social & Discussion & Qualitative & - & National & [120] \\
\hline & - Investigation the policies regarding to autonomous desalination in the $\mathrm{EU}$ & Social & Discussion & Qualitative & - & Regional & [123] \\
\hline & $\begin{array}{l}\text { - Investigation the policies regarding to autonomous } \\
\text { desalination in Turkey }\end{array}$ & Social & Discussion & Qualitative & - & National & [124] \\
\hline & $\begin{array}{l}\text { - Evaluating the social acceptance of RO units powering } \\
\text { by solar electricity using surveys }\end{array}$ & Social & Discussion & Qualitative & - & Rural & [118] \\
\hline & - Proposing a framework to evaluate water-energy polices & Policy & Discussion & Qualitative & - & Regional & [122] \\
\hline & $\begin{array}{l}\text { - Studying decentralized solar-powered desalination } \\
\text { systems in remote regions }\end{array}$ & Sustainability & Review & Qualitative & - & - & [29] \\
\hline & $\begin{array}{l}\text { - Integrating wave energy converters with desalination } \\
\text { technologies for commercialization of wave energy }\end{array}$ & Technical and Economic & Review & Qualitative & - & Island (remote) & [126] \\
\hline & $\begin{array}{l}\text { - Investigating the potential and development of } \\
\text { ocean-based power generation for desalination systems }\end{array}$ & Sustainability & Review & Qualitative & - & - & [23] \\
\hline \multirow[t]{15}{*}{$\begin{array}{l}\text { Short-Term/ } \\
\text { Operation }\end{array}$} & $\begin{array}{l}\text { - Integration of MSF desalination, solar thermal power, } \\
\text { and hydrogen production processes to achieve synergy }\end{array}$ & Technical & Process simulation & Quantitative & Deterministic & City & [57] \\
\hline & $\begin{array}{l}\text { - Co-locating pumped hydro storage with reverse } \\
\text { osmosis desalination plant }\end{array}$ & Technical and Environmental & Optimization & Quantitative & Deterministic & City & [30] \\
\hline & $\begin{array}{l}\text { - Operating an MED desalination process by ocean energy (thermal } \\
\text { energy which is harnessed from seawater temperature gradient) }\end{array}$ & Technical & Process simulation & Quantitative & Deterministic & Stand-alone & [64] \\
\hline & $\begin{array}{l}\text { - Proposing a tool for operating a reverse electrodialysis } \\
\text { system to produce power (salinity gradient power) }\end{array}$ & Technical & Process simulation & Quantitative & Deterministic & Laboratory scale & [51] \\
\hline & $\begin{array}{l}\text { - Studying optimal climate conditions for operating small-scaled } \\
\text { RO desalination units coupled with PV systems }\end{array}$ & Technical & Experimental & Quantitative & Deterministic & Laboratory scale & [85] \\
\hline & $\begin{array}{l}\text { - Studying the capability of an RO desalination plant to } \\
\text { manage the variability of renewable energy production }\end{array}$ & Technical & Process simulation & Quantitative & Deterministic & City & [59] \\
\hline & $\begin{array}{l}\text { - Studying the performance of a combination of the MED process } \\
\text { with solar still desalination powered by solar thermal and waste heat }\end{array}$ & Technical & Experimental & Quantitative & Deterministic & Laboratory scale & [86] \\
\hline & $\begin{array}{l}\text { - Operating an MSF desalination unit powered with a hybrid energy } \\
\text { system including solar, geothermal, and ocean thermal energy }\end{array}$ & Technical & Process design & Quantitative & Deterministic & - & [127] \\
\hline & $\begin{array}{l}\text { - Modeling the integration of MED unit with solar and } \\
\text { geothermal resources }\end{array}$ & Technical & Process simulation & Quantitative & Deterministic & Island & [40] \\
\hline & $\begin{array}{l}\text { - Introducing an energy management and control system for } \\
\text { an RO desalination connected to a DC micro-grid (PV-Battery) }\end{array}$ & Technical and Economic & Fuzzy optimization & Quantitative & Deterministic & Island & [76] \\
\hline & $\begin{array}{l}\text { - Using concentrating solar power for a MED process and electricity } \\
\text { production as a hybrid system }\end{array}$ & Technical and Economic & Process design & Quantitative & Deterministic & City & [61] \\
\hline & $\begin{array}{l}\text { - Evaluating the optimal operation of an MSF desalination system } \\
\text { powered by solar thermal energy }\end{array}$ & Technical and Economic & Experimental & Quantitative & Deterministic & Laboratory scale & [68] \\
\hline & $\begin{array}{l}\text { - Considering membrane fouling during intermittent operation in } \\
\text { designing PV powered RO installations }\end{array}$ & Technical and Economic & Process simulation & Quantitative & Deterministic & Laboratory scale & [96] \\
\hline & $\begin{array}{l}\text { - Shifting load using desalination demand as a flexible load for } \\
\text { increasing the share of renewable resources in the energy system }\end{array}$ & Technical and Economic & Optimization & Quantitative & Deterministic & Island & [54] \\
\hline & $\begin{array}{l}\text { - Evaluating the potential of water desalination and distribution } \\
\text { for load shifting in an off-grid remote energy system }\end{array}$ & Technical & Linear optimization & Quantitative & Monte-Carlo & Island & [80] \\
\hline
\end{tabular}


Table 7. Cont.

\begin{tabular}{|c|c|c|c|c|c|c|c|}
\hline Horizon & Description of the System & Nexus & Approach & Analysis & Uncertainty Level & Geographical Scale & Ref. \\
\hline \multirow{22}{*}{$\begin{array}{l}\text { Long-Term/ } \\
\text { Planning }\end{array}$} & - Design a cost-effective energy system for small desalination plant & Economic & Optimization & Quantitative & Deterministic & Rural & [49] \\
\hline & $\begin{array}{l}\text { - Coupling PV and CSP with RO and MED plants to minimize } \\
\text { the cost and to maximize the RE penetration in an island }\end{array}$ & Economic & Optimization & Quantitative & Deterministic & Island & [71] \\
\hline & $\begin{array}{l}\text { - Investigating the potential of RO plants to meet } \\
\text { future water demand }\end{array}$ & Economic-Environmental & System dynamics & Quantitative & Deterministic & State & [128] \\
\hline & $\begin{array}{l}\text { - Proposing scenarios to achieve an electricity system } \\
\text { with net-zero emission }\end{array}$ & Economic & LP Optimization & Quantitative & Deterministic & National & [104] \\
\hline & $\begin{array}{l}\text { - Minimizing the total cost and GHG emissions of } \\
\text { a hybrid energy system coupled with an RO plant }\end{array}$ & Economic and Environmental & Multi-object Optimization & Quantitative & Stochastic & - & [43] \\
\hline & $\begin{array}{l}\text { - Evaluating life cycle GHG emissions of different } \\
\text { desalination technologies coupling with renewables }\end{array}$ & Environmental & LCA & Quantitative & Deterministic & - & [115] \\
\hline & $\begin{array}{l}\text { - Evaluating the environmental impacts of different } \\
\text { desalination technologies coupling with solar resources }\end{array}$ & Environmental & LCA & Quantitative & Deterministic & Rural & [63] \\
\hline & - Considering carbon tax as an external cost of desalination process & Economic & - & Quantitative & Deterministic & National & [105] \\
\hline & $\begin{array}{l}\text { - Identifying regions that are suitable for deployment } \\
\text { of RO units coupled with solar energy supplies }\end{array}$ & Economic and Technical & GIS & Quantitative & Deterministic & Global & [113] \\
\hline & $\begin{array}{l}\text { - Evaluating the potential of wave energy resources } \\
\text { to provide the power demand of desalination plants }\end{array}$ & Environmental and Technical & - & Quantitative & Deterministic & Island & [73] \\
\hline & $\begin{array}{l}\text { - Evaluating the environmental impacts for } \\
\text { open-intake pretreatment and subsurface } \\
\text { intake pretreatment of RO desalination plants }\end{array}$ & Environmental & LCA & Quantitative & Deterministic & City & [36] \\
\hline & $\begin{array}{l}\text { - Evaluating the environmental impacts RO desalination plants } \\
\text { powered by hybrid renewable energy resources and the electricity grid }\end{array}$ & Environmental & LCA & Quantitative & Deterministic & City & [50] \\
\hline & $\begin{array}{l}\text { - Studying the scenarios to achieve } 100 \% \text { RE in Iran by } \\
\text { considering electricity demand of RO desalination by } 2050\end{array}$ & Economic & LP Optimization & Quantitative & Deterministic & National & [38] \\
\hline & $\begin{array}{l}\text { - Designing a sustainable desalination system powered with } \\
\text { renewable energy resources }\end{array}$ & Sustainability & AHP & Quantitative & Deterministic & Island & [45] \\
\hline & $\begin{array}{l}\text { - Evaluating the feasibility of exchanging desalinated } \\
\text { water with renewable electricity }\end{array}$ & Technical and Economic & Optimization & Quantitative & Deterministic & Multi-national & [46] \\
\hline & - Evaluating the GHG emissions of different water sources & Environmental & LCA & Quantitative & Deterministic & City & [18] \\
\hline & $\begin{array}{l}\text { - Investigation on the economic impacts and } \mathrm{CO}_{2} \text { footprint } \\
\text { of desalination units }\end{array}$ & Environmental and Economic & Triple-I light & Quantitative & Deterministic & City & [27] \\
\hline & $\begin{array}{l}\text { - Investigating the role of the desalination sector to achieve a } 100 \\
\text { percent renewable energy system in Saudi Arabia }\end{array}$ & Technical and Economic & linear optimization & Quantitative & Deterministic & National & [39,40] \\
\hline & $\begin{array}{l}\text { - Achieving } 100 \text { percent renewable energy } \\
\text { in India by considering desalination demand }\end{array}$ & Technical and Economic & linear optimization & Quantitative & Deterministic & National & [84] \\
\hline & $\begin{array}{l}\text { - Proposing a spatial model to assess potential technical and } \\
\text { economically viable site locations for RO desalination facilities } \\
\text { powered by renewables }\end{array}$ & Technical and Economic & Multi-criteria & Quantitative & Deterministic & Regional & [31] \\
\hline & $\begin{array}{l}\text { - Finding the optimal size and configuration of a small-scaled RO } \\
\text { desalination unit coupled with a PV system (including battery } \\
\text { storage and water storage) }\end{array}$ & Technical and Economic & Fuzzy Optimization & Quantitative & Deterministic & Island & [74] \\
\hline & $\begin{array}{l}\text { - Technical feasibility of using RO desalination units powered by } \\
\text { wave energy as an alternative for imported water }\end{array}$ & Technical & Optimization & Quantitative & Deterministic & Island & [47] \\
\hline
\end{tabular}


Table 7. Cont.

\begin{tabular}{|c|c|c|c|c|c|c|c|}
\hline Horizon & Description of the System & Nexus & Approach & Analysis & Uncertainty Level & Geographical Scale & Ref. \\
\hline & $\begin{array}{l}\text { - Calculating the optimal size of renewable energy supply } \\
\text { (wind turbine and PV) for RO desalination units with a solar } \\
\text { preheating water system }\end{array}$ & Technical and Economic & Optimization & Quantitative & Deterministic & Regional & [58] \\
\hline & $\begin{array}{l}\text { - Estimating the cost of providing water demand using } \\
\text { renewable-powered RO desalination plants for regions } \\
\text { facing water scarcity in } 2030\end{array}$ & Economic & Linear Optimization & Quantitative & Deterministic & Global & [93] \\
\hline & $\begin{array}{l}\text { - Developing a tool for sizing RO desalination plants powered } \\
\text { by renewables units }\end{array}$ & Economic & Optimization & Quantitative & Deterministic & Island & [48] \\
\hline & $\begin{array}{l}\text { - Investigating the economic feasibility of desalinating } \\
\text { agriculture drainage water using the MED process powered } \\
\text { by solar thermal resources }\end{array}$ & Economic & Optimization & Quantitative & Deterministic & Region & [91] \\
\hline & $\begin{array}{l}\text { - Evaluating the technical and economic feasibility of } \\
\text { RO desalination units powered by } \\
\text { distributed PV-battery systems in Myanmar }\end{array}$ & Technical and Economic & Optimization & Quantitative & Deterministic & National & [87] \\
\hline & $\begin{array}{l}\text { - Considering desalination energy demand in the transition } \\
\text { to a } 100 \text { percent renewable system in South and Central America }\end{array}$ & Technical and Economic & Optimization & Quantitative & Deterministic & Multi-National & [60] \\
\hline & $\begin{array}{l}\text { - Studying the benefits of the integration of RO desalination } \\
\text { energy demand in the transition to a } 100 \text { percent renewable } \\
\text { energy system for India and the South Asian Association } \\
\text { for Regional Cooperation }\end{array}$ & Technical and Economic & Optimization & Quantitative & Deterministic & Multi-National & [129] \\
\hline & $\begin{array}{l}\text { - Minimizing the cost and } \mathrm{CO}_{2} \text { emissions of an energy system } \\
\text { including PV, wind turbine, hydrogen electrolyzer, } \\
\text { battery, and hydrogen storage coupled with } \\
\text { an RO desalination unit }\end{array}$ & Economic and Environmental & Heuristic optimization & Quantitative & Deterministic & City & [41] \\
\hline & $\begin{array}{l}\text { - Investigating the role of RO desalination demand in the } \\
\text { transition to a } 100 \text { percent solar electricity system in Pakistan } \\
\text { by } 2050\end{array}$ & Economic & Linear optimization & Quantitative & Deterministic & National & [52] \\
\hline & $\begin{array}{l}\text { - Proposing a dynamic approach to consider the operation of an } \\
\text { RO plant in sizing the PV and wind turbine energy system }\end{array}$ & Technical and Economic & Multi-objective optimization & Quantitative & Deterministic & Island & [79] \\
\hline & $\begin{array}{l}\text { - Forecasting } \mathrm{CO}_{2} \text { emissions from different energy systems } \\
\text { providing desalination power demand for an Island by } 2020\end{array}$ & Environmental & Scenario-based & Quantitative & Deterministic & Island & [44] \\
\hline & $\begin{array}{l}\text { - Estimating the potential amount of desalination water } \\
\text { powering with solar and wind electricity in Iran }\end{array}$ & Technical and Economic & Scenario-based & Quantitative & Deterministic & National & [130] \\
\hline & $\begin{array}{l}\text { - Investigating the technical and economic feasibility of RO units } \\
\text { powered by off-grid PV systems in remote case studies in Iran }\end{array}$ & Technical and Economic & Fuzzy optimization & Quantitative & Deterministic & Rural & [69] \\
\hline & $\begin{array}{l}\text { - Evaluating on-grid decentralized or distributed } \\
\text { renewable-powered desalination systems for sustainable water } \\
\text { and energy supply planning }\end{array}$ & Sustainability & Hybrid approach & Quantitative & Deterministic & National & [5] \\
\hline & $\begin{array}{l}\text { - Comparing a centralized water desalination system to a } \\
\text { distributed desalination system powered by solar electricity } \\
\text { resources in Australia }\end{array}$ & Technical and Economic & Optimization & Quantitative & Deterministic & National & [55] \\
\hline \multirow{2}{*}{\multicolumn{2}{|c|}{$\begin{array}{l}\text { Number of studies/ } \\
\text { Total studies }\end{array}$}} & Technical & Environmental & Economic & Social & Qualitative & Quantitative \\
\hline & & $38 / 61$ & $10 / 61$ & $37 / 61$ & $10 / 61$ & $9 / 61$ & $52 / 61$ \\
\hline
\end{tabular}




\section{Results and Discussion}

Table 7 depicts the aspects of sustainability that each study investigated. Technical, economic, and environmental aspects of desalination technologies receive considerable attention among studies $[23,29,45]$ compared with the social aspect (only 10 studies).

Integrating desalination plants with renewable resources reduces GHG emissions from desalination facilities, which are currently one of the main environmental impacts of these systems. It also improves the social acceptance of desalination systems. How to consider uncertainty is a critical part of modeling and it gets more important in integrating variable renewable resources with desalination facilities. Table 7 shows that more studies are needed to cover uncertainties in the integrated renewable desalination systems (both supply-side and demand-side).

Concerning the technical aspect, there is a contradiction among studies. Figure 3 reveals that renewable desalination systems are suitable for a small capacity of water production, while many studies are focusing on large desalination capacities in this field of study. It is possible to operate large membrane-based desalination facilities (mainly RO) using the excess electricity production from variable renewables, but studies are limited and the techno-economic performance is still uncertain. Studies have investigated the potential of large RO desalination plants to compensate for the fluctuation of the variable renewable electricity production, which is relatively low compared to small-scaled desalination systems. The compatibility of other desalination technologies (small- to large-scale) needs further investigation.

There is a gap among studies in the investigation of distributed water systems, which are compatible with renewable resources and can operate as flexible loads to integrate with variable renewable electricity production. Only two studies investigated distributed water systems $[5,55]$. Instead of one centralized desalination unit, these distributed water systems include several small-scale desalination units. Distributed water systems can moderate the effluent-associated (concentrated salinity and thermal pollution) environmental impact of the desalination process by providing multiple options for site locations to distribute the brine discharge (in order to reduce the salinity) and avoid discharging brine into sensitive ecosystems.

Public education and participation in developing desalination projects are essential [9]. Labor costs account for more than 10 percent of the operating costs of desalination processes and this reaches 15 percent for RO plants. A study [131] estimated the urban-rural gap in 101 developed and developing countries using surveys and national labor statistics. The results indicated that average urban wage advantages were 38 percent, half of which cannot be explained by differences in average skills across the markets. Due to size compatibility, the decentralized desalination systems are suitable for deployment in rural areas, thereby mitigating the labor cost of desalination projects. Energy savings from water distribution and transfer are also considerable in the distributed water systems, which cause further cost reductions. Moreover, energy storage systems are responsible for a significant share of renewable energy cost, which is avoidable with the application of desalination units as flexible loads in the regions facing water scarcity and having access to water sources to be desalinated. Besides, the freedom to choose site locations for distributed desalination systems (multiple locations) is larger than that for centralized systems (only one location). Selecting locations in which the feed-water suits the desalination technology better (causing cost reduction, as discussed in previous sections) could mitigate environmental impacts, namely intake-related impacts and effluent-related impacts. Furthermore, presenting such multiple location alternatives allows the policy-makers to allocate desalination to other target users apart from potable water. It is notable that potable water has been the main target product for studies and there is no estimation for the cost of water produced for other purposes. As an example, water containing high levels of salt and boron, even after first-pass RO water production, needs to pass through an additional $\mathrm{RO}$ stage to achieve good-quality water that is suitable for drinking. The second-pass stage can increase the total cost of the first-pass desalination process by 10 to 25 percent. For most industrial and agricultural applications, it is unnecessary to 
design this second stage pass. The current cost of desalination product water includes the second-pass stage, which is responsible for up to 25 percent of total $\mathrm{RO}$ water desalination costs.

Conventional thermal desalination technologies are now well-proven and mature. Thus, further improvement in these technologies is relatively limited. Continuous innovation in RO desalination technology in the last twenty years has reduced the energy consumption per unit of product water to $1.8 \mathrm{KWh} / \mathrm{m}^{3}$, which is close to the theoretical minimum required energy for seawater desalination. It means a further large reduction in energy consumption is not expected for desalination technologies. However, further significant advances in renewable energy technologies in the future are highly likely to decrease the water cost of renewable desalination. Besides, future advances in membrane technology (increasing water productivity per area) are predicted, which could cause up to a 20 percent cost reduction in the next five years. Experimental studies [132,133] showed that CDI technology is effective and reliable for brackish water treatment in remote areas in Australia. Advances in electrode materials are crucial to developing CDI technology in the future for decentralized brackish water treatment [134]; in the meantime, further investigation is required for the integration of this technology with renewables.

Considering all of these cost reductions and developments, desalination is an expensive water supply compared to other conventional fresh-water resources and needs heavy national investments and subsidies from governments for the next few decades. Policy-makers and governments should consider social equity in designing plans and budgeting as a social aspect of desalination projects. Above technical and environmental aspects, different potential target users and system configurations (centralized or decentralized) should be investigated based on equity, wealth distribution, and social acceptance. Furthermore, desalination is economically and politically important to achieving self-reliance for specific regions, such as the Middle East and Singapore. When achieving this goal, it is important to examine the resilience of desalination systems further. For instance, in the case of technical failure or war, the centralized desalination systems and potable desalination units are more vulnerable, while the distributed desalination systems and agriculture users are more resilient compared to domestic users. Table 8 compares the distributed and centralized desalination systems powered by renewable energy resources.

Table 8. Comparison between distributed and centralized desalination systems powered by renewable energy resources.

\begin{tabular}{|c|c|c|}
\hline $\begin{array}{l}\text { Sustainability } \\
\text { Aspect }\end{array}$ & Decentralized Desalination System & Centralized Desalination System \\
\hline Technical & $\begin{array}{l}\text { - The technology is under development } \\
\text { - High potential to compensate the fluctuation due to VRE } \\
\text { - High reliability }\end{array}$ & $\begin{array}{l}\text { - The technology is mature } \\
\text { - Needs energy storage to operate with VRE }\end{array}$ \\
\hline Economic & $\begin{array}{l}\text { - High capital cost } \\
\text { - Low maintenance cost } \\
\text { - Saving cost from water distribution and transfer }\end{array}$ & $\begin{array}{l}\text { - Low capital cost } \\
\text { - High maintenance cost }\end{array}$ \\
\hline Environmental & $\begin{array}{l}\text { - Less thermal pollution } \\
\text { - No need for diffuser to decrease the salinity of effluent } \\
\text { - Multiple site locations to decrease the environmental impacts } \\
\text { - Difficult to monitor the effluent (regulations) }\end{array}$ & $\begin{array}{l}\text { - Impacts on marine ecosystem due to thermal pollution } \\
\text { - Need for diffuser to decrease the salinity of effluent } \\
\text { - Producing water in one location } \\
\text { - It is practical to monitor effluent (regulations) }\end{array}$ \\
\hline Social & $\begin{array}{l}\text { - High reliability and security } \\
\text { - Wealth distribution and equity }\end{array}$ & - Has less of a financial burden on society \\
\hline
\end{tabular}

\section{Conclusions}

The share of desalination in the fresh-water supply is increasing around the world. Currently, desalination facilities are mainly fossil-fuel-based, which has environmental impacts due to emissions. This review study sheds light on the potential of renewable energy resources to integrate with desalination technologies for making the whole system more sustainable. Renewable desalination systems are more suitable to produce water on a small scale; in consequence these systems need to be studied in the same scope. Decentralized or distributed renewable desalination systems (mainly membrane-based desalination technologies that are consuming electricity) are promising future 
systems. These systems have the potential to compensate for the fluctuating power production of variable renewables, to reduce GHG emissions, and to mitigate effluent-associated environmental issues, and are more reliable and secure. Ongoing progress in renewable desalination technologies will decrease the cost of renewable energy generation and water production. Further cost reduction is expected from targeting other sectors such as agriculture, and from distributed water systems, which need less energy for water distribution and transfer and labor costs, and benefit from desalination units as flexible loads in energy systems. Moreover, integrating renewables with desalination systems has positive impacts on the social acceptance of these systems. Considering the social aspect and demand-side in the decision-making process makes the transition models more realistic and effective towards sustainability.

Author Contributions: E.A. designed, conceptualized, and conducted the review, analyzed the results, visualized, and wrote the manuscript. B.M. reviewed, edited, and visualized. B.M., B.M.-I., and T.T. gave guidance, provided the materials, and helped to improve the quality of the work. All authors have read and agreed to the published version of the manuscript.

Funding: This research received no external funding.

Conflicts of Interest: The authors declare no conflict of interest.

\section{References}

1. Mekonnen, M.M.; Hoekstra, A.Y. Four billion people facing severe water scarcity. Sci. Adv. 2016, 2, e1500323. [CrossRef] [PubMed]

2. United Nations Environment Programme (UNEP). Options for Decoupling Economic Growth from Water Use and Water Pollution. 2017. Available online: https://www.resourcepanel.org/reports/optionsdecoupling-economic-growth-water-use-and-water-pollution (accessed on 7 May 2020).

3. Katz, D. Book Review: "Let There Be Water: Israel's Solution for a Water-Starved World". Water Econ. Policy 2017, 3, 4. [CrossRef]

4. World Bank. The Role of Desalination in an Increasingly Water-Scarce World; Water Papers; World Bank: Washington, DC, USA, 2019. [CrossRef]

5. Ahmadi, E.; McLellan, B.; Ogata, S.; Mohammadi-Ivatloo, B.; Tezuka, T. An Integrated Planning Framework for Sustainable Water and Energy Supply. Sustainability 2020, 12, 4295. [CrossRef]

6. Aliewi, A.; El-Sayed, E.; Akbar, A.; Hadi, K.; Al-Rashed, M. Evaluation of desalination and other strategic management options using multi-criteria decision analysis in Kuwait. Desalination 2017, 413, 40-51. [CrossRef]

7. ALMAR Water Solution. Desalination Technologies and Economics: CAPEX, OPEX \& Technological Game Changers to Come. 2017. Available online: https:/ / www.cmimarseille.org/knowledge-library/desalinationtechnologies-and-economics-capex-opex-technological-game-changers-0 (accessed on 15 June 2020).

8. Khan, J.; Arsalan, M.H. Solar power technologies for sustainable electricity generation: A review. Renew. Sustain. Energy Rev. 2016, 55, 414-425. [CrossRef]

9. Gude, V. Desalination and sustainability—An appraisal and current perspective. Water Res. 2016, 89, 87-106. [CrossRef]

10. Alkaisi, A.; Mossad, R.; Sharifian-Barforoush, A. A Review of the Water Desalination Systems Integrated with Renewable Energy. Energy Procedia 2017, 110, 268-274. [CrossRef]

11. International Energy Agency. World Energy Outlook 2016; Organisation for Economic Co-Operation and Development OECD: Paris, France, 2016; p. 684, [CrossRef]

12. Pakdel, M.J.V.; Sohrabi, F.; Mohammadi-Ivatloo, B. Multi-objective optimization of energy and water management in networked hubs considering transactive energy. J. Clean. Prod. 2020, 2020, 121936. [CrossRef]

13. Kılkış, Ş. Sustainable development of energy, water and environment systems index for Southeast European cities. J. Clean. Prod. 2016, 130, 222-234. [CrossRef]

14. Cai, Y.; Cai, J.; Xu, L.; Tan, Q.; Xu, Q. Integrated risk analysis of water-energy nexus systems based on systems dynamics, orthogonal design and copula analysis. Renew. Sustain. Energy Rev. 2019, 99, 125-137. [CrossRef] 
15. Xie, X.; Jia, B.; Han, G.; Wu, S.; Dai, J.; Weinberg, J. A historical data analysis of water-energy nexus in the past 30 years urbanization of Wuxi city, China. Environ. Prog. Sustain. Energy 2017, 37, 46-55. [CrossRef]

16. Stokes-Draut, J.; Taptich, M.; Kavvada, O.; Horvath, A. Evaluating the electricity intensity of evolving water supply mixes: The case of California's water network. Environ. Res. Lett. 2017, 12, 11400. [CrossRef]

17. Sperling, J.B.; Ramaswami, A. Cities and budget-based management of the energy-water-climate nexus: Case studies in transportation policy, infrastructure systems, and urban utility risk management. Environ. Prog. Sustain. Energy 2015, 37, 91-107. [CrossRef]

18. Stokes, J.; Horvath, A. Energy and air emission effects of water supply. Environ. Sci. Technol. 2009, 43, 2680-2687. [CrossRef]

19. Valek, A.M.; Sušnik, J.; Grafakos, S. Quantification of the urban water-energy nexus in Mexico City, Mexico, with an assessment of water-system related carbon emissions. Sci. Total Environ. 2017, 590-591, $258-268$. [CrossRef]

20. Bolwig, S.; Bazbauers, G.; Klitkou, A.; Lund, P.D.; Blumberga, A.; Gravelsins, A.; Blumberga, D. Review of modelling energy transitions pathways with application to energy system flexibility. Renew. Sustain. Energy Rev. 2019, 101, 440-452. [CrossRef]

21. Cherp, A.; Vinichenko, V.; Jewell, J.; Brutschin, E.; Sovacool, B. Integrating techno-economic, socio-technical and political perspectives on national energy transitions: A meta-theoretical framework. Energy Res. Soc. Sci. 2018, 37, 175-190. [CrossRef]

22. Stercke, S.D.; Mijic, A.; Buytaert, W.; Chaturvedi, V. Modelling the dynamic interactions between London's water and energy systems from an end-use perspective. Appl. Energy 2018, 230, 615-626. [CrossRef]

23. Li, Z.; Siddiqi, A.; Anadon, L.D.; Narayanamurti, V. Towards sustainability in water-energy nexus: Ocean energy for seawater desalination. Renew. Sustain. Energy Rev. 2018, 82, 3833-3847. [CrossRef]

24. Kalogirou, S. Seawater desalination using renewable energy sources. Prog. Energy Combust. Sci. 2005, 31, 242-281. [CrossRef]

25. Zhang, W.; Mossad, M.; Yazdi, J.S.; Zou, L. A statistical experimental investigation on arsenic removal using capacitive deionization. Desalin. Water Treat. 2016, 57, 3254-3260. [CrossRef]

26. Zhang, W.; Jia, B. Toward anti-fouling capacitive deionization by using visible-light reduced $\mathrm{TiO}_{2} /$ graphene nanocomposites. MRS Commun. 2015, 5, 613-617. [CrossRef]

27. Tokui, Y.; Moriguchi, H.; Nishi, Y. Comprehensive environmental assessment of seawater desalination plants: Multistage flash distillation and reverse osmosis membrane types in Saudi Arabia. Desalination 2014, 351, 145-150. [CrossRef]

28. Vakilifard, N.; Anda, M.; Bahri, P.A.; Ho, G. The role of water-energy nexus in optimising water supply systems: Review of techniques and approaches. Renew. Sustain. Energy Rev. 2018, 82, 1424-1432. [CrossRef]

29. Kharraz, J.; Richards, B.; Schafer, A. Autonomous Solar-Powered Desalination Systems for Remote Communities. In Desalination Sustainability: A Technical, Socioeconomic, and Environmental Approach; Elsevier: Amsterdam, The Netherlands, 2017; pp. 75-125. [CrossRef]

30. Slocum, A.H.; Haji, M.N.; Trimble, A.Z.; Ferrara, M.; Ghaemsaidi, S.J. Integrated Pumped Hydro Reverse Osmosis systems. Sustain. Energy Technol. Assess. 2016, 18, 80-99. [CrossRef]

31. Aminfard, S.; Davidson, F.; Webber, M. Multi-layered spatial methodology for assessing the technical and economic viability of using renewable energy to power brackish groundwater desalination. Desalination 2019, 450, 12-20. [CrossRef]

32. Ramos, A.; Chatzopoulou, M.A.; Guarracino, I.; Freeman, J.; Markides, C.N. Hybrid photovoltaic-thermal solar systems for combined heating, cooling and power provision in the urban environment. Energy Convers. Manag. 2017, 150, 838-850. [CrossRef]

33. Kang, C.-N.; Cho, S.-H. Thermal and Electrical Energy Mix Optimization(EMO) Method for Real Large-scaled Residential Town Plan. J. Electr. Eng. Technol. 2018, 13, 513-520.

34. Tarroja, B.; Chiang, F.; AghaKouchak, A.; Samuelsen, S. Assessing future water resource constraints on thermally based renewable energy resources in California. Appl. Energy 2018, 226, 49-60. [CrossRef]

35. Uche, J.; Acevedo, L.; Cirez, F.; Uson, S.; Martinez-Gracia, A.; Bayod-Rujula, A. Analysis of a domestic trigeneration scheme with hybrid renewable energy sources and desalting techniques. J. Clean. Prod. 2019, 212, 1409-1422. [CrossRef]

36. Al-Kaabi, A.; Mackey, H. Environmental assessment of intake alternatives for seawater reverse osmosis in the Arabian Gulf. J. Environ. Manag. 2019, 242, 22-30. [CrossRef] [PubMed] 
37. Birge, D.; Berger, A. Transitioning to low-carbon suburbs in hot-arid regions: A case-study of Emirati villas in Abu Dhabi. Build. Environ. 2019, 147,77-96. [CrossRef]

38. Ghorbani, N.; Aghahosseini, A.; Breyer, C. Transition towards a 100\% Renewable Energy System and the Role of Storage Technologies: A Case Study of Iran. Energy Procedia 2017, 135, 23-36. [CrossRef]

39. Caldera, U.; Bogdanov, D.; Afanasyeva, S.; Breyer, C. Role of Seawater Desalination in the Management of an Integrated Water and 100\% Renewable Energy Based Power Sector in Saudi Arabia. Water 2018, 10, 3. [CrossRef]

40. Caldera, U.; Breyer, C. Impact of Battery and Water Storage on the Transition to an Integrated $100 \%$ Renewable Energy Power System for Saudi Arabia. Energy Procedia 2017, 135, 126-142. [CrossRef]

41. Abdelshafy, A.M.; Hassan, H.; Jurasz, J. Optimal design of a grid-connected desalination plant powered by renewable energy resources using a hybrid PSO-GWO approach. Energy Convers. Manag. 2018, 173, 331-347. [CrossRef]

42. Salama, L.; Abdalla, K. Design and analysis of a solar photovoltaic powered seawater reverse osmosis plant in the southern region of the gaza strip. Desalin. Water Treat. 2019, 143, 96-101. [CrossRef]

43. Li, Q.; Loy-Benitez, J.; Nam, K.; Hwangbo, S.; Rashidi, J.; Yoo, C. Sustainable and reliable design of reverse osmosis desalination with hybrid renewable energy systems through supply chain forecasting using recurrent neural networks. Energy 2019, 178, 277-292. [CrossRef]

44. Jaime Sadhwani, J.; Sagaseta de Ilurdoz, M. Primary energy consumption in desalination: The case of Gran Canaria. Desalination 2019, 452, 219-229. [CrossRef]

45. Marini, M.; Palomba, C.; Rizzi, P.; Casti, E.; Marcia, A.; Paderi, M. A multicriteria analysis method as decision-making tool for sustainable desalination: The asinara island case study. Desalin. Water Treat. 2017, 61, 274-283. [CrossRef]

46. Katz, D.; Shafran, A. Transboundary exchanges of renewable energy and desalinatedwater in the Middle East. Energies 2019, 12, 1455. [CrossRef]

47. Corsini, A.; Tortora, E.; Cima, E. Preliminary assessment of wave energy use in an off-grid minor island desalination plant. Energy Procedia 2015, 82, 789-796. [CrossRef]

48. Mentis, D.; Karalis, G.; Zervos, A.; Howells, M.; Taliotis, C.; Bazilian, M.; Rogner, H. Desalination using renewable energy sources on the arid islands of South Aegean Sea. Energy 2016, 94, 262-272. [CrossRef]

49. Fornarelli, R.; Shahnia, F.; Anda, M.; Bahri, P.A.; Ho, G. Selecting an economically suitable and sustainable solution for a renewable energy-powered water desalination system: A rural Australian case study. Desalination 2018, 435, 128-139. [CrossRef]

50. Shahabi, M.; McHugh, A.; Anda, M.; Ho, G. Environmental life cycle assessment of seawater reverse osmosis desalination plant powered by renewable energy. Renew. Energy 2014, 67, 53-58. [CrossRef]

51. Nagaraj, R.; Murthy, D.; Rajput, M. Modeling Renewables Based Hybrid Power System with Desalination Plant Load Using Neural Networks. Distrib. Gener. Altern. Energy J. 2019, 34, 32-46. [CrossRef]

52. Sadiqa, A.; Gulagi, A.; Breyer, C. Energy transition roadmap towards $100 \%$ renewable energy and role of storage technologies for Pakistan by 2050. Energy 2018, 147, 518-533. [CrossRef]

53. Khan, M.; Rehman, S.; Al-Sulaiman, F. A hybrid renewable energy system as a potential energy source for water desalination using reverse osmosis: A review. Renew. Sustain. Energy Rev. 2018, 97, 456-477. [CrossRef]

54. Hamilton, J.; Negnevitsky, M.; Wang, X.; Lyden, S. High penetration renewable generation within Australian isolated and remote power systems. Energy 2019, 168, 684-692. [CrossRef]

55. Vakilifard, N.; Bahri, P.A.; Anda, M.; Ho, G. An interactive planning model for sustainable urban water and energy supply. Appl. Energy 2019, 235, 332-345. [CrossRef]

56. Cavalcante, R., Jr.; Freitas, M.; da Silva, N.; de Azevedo Filho, F. Sustainable groundwater exploitation aiming at the reduction of water vulnerability in the Brazilian semi-arid region. Energies 2019, 12, 904. [CrossRef]

57. Gencer, E.; Agrawal, R. Toward supplying food, energy, and water demand: Integrated solar desalination process synthesis with power and hydrogen coproduction. Resour. Conserv. Recycl. 2018, 133, 331-342. [CrossRef]

58. Gold, G.; Webber, M. The energy-water nexus: An analysis and comparison of various configurations integrating desalination with renewable power. Resources 2015, 4, 227-276. [CrossRef]

59. Kim, J.; Chen, J.; Garcia, H. Modeling, control, and dynamic performance analysis of a reverse osmosis desalination plant integrated within hybrid energy systems. Energy 2016, 112, 52-66. [CrossRef]

60. De Barbosa, L.; Bogdanov, D.; Vainikka, P.; Breyer, C. Hydro, wind and solar power as a base for a $100 \%$ renewable energy supply for South and Central America. PLoS ONE 2017, 12, e0173820. [CrossRef] [PubMed] 
61. Mata-Torres, C.; Escobar, R.; Cardemil, J.; Simsek, Y.; Matute, J. Solar polygeneration for electricity production and desalination: Case studies in Venezuela and northern Chile. Renew. Energy 2017, 101,387-398. [CrossRef]

62. Aghahosseini, A.; Bogdanov, D.; Barbosa, L.; Breyer, C. Analysing the feasibility of powering the Americas with renewable energy and inter-regional grid interconnections by 2030. Renew. Sustain. Energy Rev. 2019, 105, 187-205. [CrossRef]

63. Jijakli, K.; Arafat, H.; Kennedy, S.; Mande, P.; Theeyattuparampil, V. How green solar desalination really is? Environmental assessment using life-cycle analysis (LCA) approach. Desalination 2012, 287, 123-131. [CrossRef]

64. Ng, K.C.; Shahzad, M.W. Sustainable desalination using ocean thermocline energy. Renew. Sustain. Energy Rev. 2018, 82, 240-246. [CrossRef]

65. Heidary, B.; Hashjin, T.; Ghobadian, B.; Roshandel, R. Optimal integration of small scale hybrid solar wind RO-MSF desalination system. Renew. Energy Focus 2018, 27, 120-134. [CrossRef]

66. Maleki, A. Design and optimization of autonomous solar-wind-reverse osmosis desalination systems coupling battery and hydrogen energy storage by an improved bee algorithm. Desalination 2018, 435, 221-234. [CrossRef]

67. Peng, W.; Maleki, A.; Rosen, M.A.; Azarikhah, P. Optimization of a hybrid system for solar-wind-based water desalination by reverse osmosis: Comparison of approaches. Desalination 2018, 442, 16-31. [CrossRef]

68. Darawsheh, I.; Islam, M.; Banat, F. Experimental characterization of a solar powered MSF desalination process performance. Therm. Sci. Eng. Prog. 2019, 10, 154-162. [CrossRef]

69. Mostafaeipour, A.; Qolipour, M.; Rezaei, M.; Babaee-Tirkolaee, E. Investigation of off-grid photovoltaic systems for a reverse osmosis desalination system: A case study. Desalination 2019, 454, 91-103. [CrossRef]

70. Rezk, H.; Sayed, E.; Al-Dhaifallah, M.; Obaid, M.; El-Sayed, A.; Abdelkareem, M.; Olabi, A. Fuel cell as an effective energy storage in reverse osmosis desalination plant powered by photovoltaic system. Energy 2019, 175, 423-433. [CrossRef]

71. Astolfi, M.; Mazzola, S.; Silva, P.; Macchi, E. A synergic integration of desalination and solar energy systems in stand-alone microgrids. Desalination 2017, 419, 169-180. [CrossRef]

72. Fernandez-Gonzalez, C.; Dominguez-Ramos, A.; Ibanez, R.; Irabien, A. Sustainability assessment of electrodialysis powered by photovoltaic solar energy for freshwater production. Renew. Sustain. Energy Rev. 2015, 47, 604-615. [CrossRef]

73. Fernandez Prieto, L.; Rodriguez Rodriguez, G.; Schallenberg Rodiguez, J. Wave energy to power a desalination plant in the north of Gran Canaria Island: Wave resource, socioeconomic and environmental assessment. J. Environ. Manag. 2019, 231, 546-551. [CrossRef]

74. Karavas, C.S.; Arvanitis, K.; Papadakis, G. Optimal technical and economic configuration of photovoltaic powered reverse osmosis desalination systems operating in autonomous mode. Desalination 2019, 466, 97-106.

75. Calise, F.; Macaluso, A.; Piacentino, A.; Vanoli, L. A novel hybrid polygeneration system supplying energy and desalinated water by renewable sources in Pantelleria Island. Energy 2017, 137, 1086-1106. [CrossRef]

76. Kyriakarakos, G.; Dounis, A.; Arvanitis, K.; Papadakis, G. Design of a Fuzzy Cognitive Maps variable-load energy management system for autonomous PV-reverse osmosis desalination systems: A simulation survey. Appl. Energy 2017, 187, 575-584. [CrossRef]

77. Li, Q.; Moya, W.; Janghorban Esfahani, I.; Rashidi, J.; Yoo, C. Integration of reverse osmosis desalination with hybrid renewable energy sources and battery storage using electricity supply and demand-driven power pinch analysis. Process. Saf. Environ. Prot. 2017, 111, 795-809. [CrossRef]

78. Kofinas, P.; Dounis, A.I.; Vouros, G.A. Fuzzy Q-Learning for multi-agent decentralized energy management in microgrids. Appl. Energy 2018, 219, 53-67. [CrossRef]

79. Giudici, F.; Castelletti, A.; Garofalo, E.; Giuliani, M.; Maier, H. Dynamic, multi-objective optimal design and operation of water-energy systems for small, off-grid islands. Appl. Energy 2019, 250, 605-616. [CrossRef]

80. Meschede, H. Increased utilisation of renewable energies through demand response in the water supply sector-A case study. Energy 2019, 175, 810-817. [CrossRef]

81. Padron, I.; Avila, D.; Marichal, G.; Rodriguez, J. Assessment of Hybrid Renewable Energy Systems to supplied energy to Autonomous Desalination Systems in two islands of the Canary Archipelago. Renew. Sustain. Energy Rev. 2019, 101, 221-230. [CrossRef] 
82. Trapanese, M.; Frazitta, V. Desalination in small islands: The case study of Lampedusa (Italy). In Proceedings of the OCEANS 2018 MTS/IEEE Charleston, Charleston, SC, USA, 22-25 October 2019. [CrossRef]

83. El-Kady, M.; El-Shibini, F. Desalination in Egypt and the future application in supplementary irrigation. Desalination 2001, 136, 63-72. [CrossRef]

84. Gulagi, A.; Bogdanov, D.; Breyer, C. The role of storage technologies in energy transition pathways towards achieving a fully sustainable energy system for India. J. Energy Storage 2018, 17, 525-539. [CrossRef]

85. Alghoul, M.; Poovanaesvaran, P.; Mohammed, M.; Fadhil, A.; Muftah, A.; Alkilani, M.; Sopian, K. Design and experimental performance of brackish water reverse osmosis desalination unit powered by $2 \mathrm{~kW}$ photovoltaic system. Renew. Energy 2016, 93, 101-114. [CrossRef]

86. Park, C.D.; Lim, B.J.; Chung, K.Y.; Lee, S.S.; Kim, Y.M. Experimental evaluation of hybrid solar still using waste heat. Desalination 2016, 379, 1-9. [CrossRef]

87. Thompson, M.; Baker, R.; Yong, N. Technical and economic evaluation of an off-grid solar desalination system in Myanmar. J. Water Supply: Res. Technol.-AQUA 2016, 65, 354-360. [CrossRef]

88. Gokcek, M. Integration of hybrid power (wind-photovoltaic-diesel-battery) and seawater reverse osmosis systems for small-scale desalination applications. Desalination 2018, 435, 210-220. [CrossRef]

89. Liu, W.; Wang, D.; Yu, X.; Wang, W.; Lan, Y.; Wang, X.; Yu, J. Multi-objective planning research on micro energy network considering desalination. Energy Procedia 2019, 158, 6502-6507. [CrossRef]

90. Ye, B.; Jiang, J.; Cang, Y. Technical and economic feasibility analysis of an energy and fresh water coupling model for an isolated island. Energy Procedia 2019, 158, 6373-6377. [CrossRef]

91. Stuber, M. Optimal design of fossil-solar hybrid thermal desalination for saline agricultural drainage water reuse. Renew. Energy 2016, 89, 552-563. [CrossRef]

92. Elimelech, M.; Phillip, W.A. The Future of Seawater Desalination: Energy, Technology, and the Environment. Science 2011, 333, 712-717. [CrossRef]

93. Caldera, U.; Bogdanov, D.; Breyer, C. Local cost of seawater RO desalination based on solar PV and wind energy: A global estimate. Desalination 2016, 385, 207-216. [CrossRef]

94. Ahmadi, E.; McLellan, B.; Ogata, S.; Tezuka, T. Modelling the water-energy-nexus to assist the design of economic and regulatory support instruments towards sustainability. In Proceedings of the Chemeca 2019: Chemical Engineering Megatrends and Elements, Sydney, NSW, Australia, 29 September-2 October 2019; p. 550.

95. Freire-Gormaly, M.; Bilton, A.M. Experimental quantification of the effect of intermittent operation on membrane performance of solar powered reverse osmosis desalination systems. Desalination 2018, 435, 188-197. [CrossRef]

96. Freire-Gormaly, M.; Bilton, A. Design of photovoltaic powered reverse osmosis desalination systems considering membrane fouling caused by intermittent operation. Renew. Energy 2019, 135, 108-121. [CrossRef]

97. Xue, Y.; Ge, Z.; Yang, L.; Du, X. Peak shaving performance of coal-fired power generating unit integrated with multi-effect distillation seawater desalination. Appl. Energy 2019, 250, 175-184. [CrossRef]

98. Gude, V. Geothermal source potential for water desalination-Current status and future perspective. Renew. Sustain. Energy Rev. 2016, 57, 1038-1065. [CrossRef]

99. Giwa, A.; Akther, N.; Housani, A.; Haris, S.; Hasan, S. Recent advances in humidification dehumidification (HDH) desalination processes: Improved designs and productivity. Renew. Sustain. Energy Rev. 2016, 57, 929-944. [CrossRef]

100. Voutchkov, N. Desalination Project Cost Estimating and Management; CRC Press: Boca Raton, FL, USA, 2018.

101. Gopi, G.; Arthanareeswaran, G.; Ismail, A.F. Perspective of renewable desalination by using membrane distillation. Chem. Eng. Res. Des. 2019, 144, 520-537. [CrossRef]

102. Gude, V. Energy storage for desalination processes powered by renewable energy and waste heat sources. Appl. Energy 2015, 137, 877-898. [CrossRef]

103. Bhojwani, S.; Topolski, K.; Mukherjee, R.; Sengupta, D.; El-Halwagi, M. Technology review and data analysis for cost assessment of water treatment systems. Sci. Total Environ. 2019, 651, 2749-2761. [CrossRef]

104. Solomon, A.; Bogdanov, D.; Breyer, C. Solar driven net zero emission electricity supply with negligible carbon cost: Israel as a case study for Sun Belt countries. Energy 2018, 155, 87-104. [CrossRef]

105. Molinos-Senante, M.; González, D. Evaluation of the economics of desalination by integrating greenhouse gas emission costs: An empirical application for Chile. Renew. Energy 2019, 133, 1327-1337. [CrossRef] 
106. Zhou, Y.; Tol, R.S.J. Evaluating the costs of desalination and water transport. Water Resour. Res. 2005, 41, 10. [CrossRef]

107. Gude, G. Renewable Energy Powered Desalination Handbook: Application and Thermodynamics; Butterworth-Heinemann: Oxford, UK, 2018.

108. World Bank. Beyond Scarcity: Water Security in the Middle East and North Africa; World Bank Group: Washington, DC, USA, 2017.

109. Negewo, B.D. Renewable Energy Desalination: An Emerging Solution to Close the Water Gap in the Middle East and North Africa; World Bank Publications: Washington, DC, USA, 2012.

110. Parrillo, V.N. Encyclopedia of Social Problems; Sage publications: Southend Oaks, CA, USA, 2008.

111. Rodriquez, M. California Environmental Protection Agency, Water Quality Control Plan Ocean Waters of California. 2015. Available online: https:/ /www.waterboards.ca.gov/water_issues/programs/ocean/docs/ cop2015.pdf (accessed on 7 May 2020).

112. Meerganz von Medeazza, G. "Direct" and socially-induced environmental impacts of desalination. Desalination 2005, 185, 57-70. [CrossRef]

113. Grubert, E.; Stillwell, A.; Webber, M. Where does solar-aided seawater desalination make sense? A method for identifying sustainable sites. Desalination 2014, 339, 10-17. [CrossRef]

114. Van der Merwe, R.; Lattemann, S.; Amy, G. A review of environmental governance and its effects on concentrate discharge from desalination plants in the Kingdom of Saudi Arabia. Desalin. Water Treat. 2013, 51, 262-272. [CrossRef]

115. Raluy, R.; Serra, L.; Uche, J. Life cycle assessment of desalination technologies integrated with renewable energies. Desalination 2005, 183, 81-93. [CrossRef]

116. Fang, A.J.; Newell, J.P.; Cousins, J.J. The energy and emissions footprint of water supply for Southern California. Environ. Res. Lett. 2015, 10, 114002. [CrossRef]

117. Chhipi-Shrestha, G.; Hewage, K.; Sadiq, R. water-energy-Carbon Nexus Modeling for Urban Water Systems: System Dynamics Approach. J. Water Resour. Plan. Manag. 2017, 143, 04017016. [CrossRef]

118. Werner, M.; Schafer, A. Social aspects of a solar-powered desalination unit for remote Australian communities. Desalination 2007, 203, 375-393. [CrossRef]

119. Von Medeazza, G. Water desalination as a long-term sustainable solution to alleviate global freshwater scarcity? A North-South approach. Desalination 2004, 169, 287-301. [CrossRef]

120. Giwa, A.; Dindi, A. An investigation of the feasibility of proposed solutions for water sustainability and security in water-stressed environment. J. Clean. Prod. 2017, 165, 721-733. [CrossRef]

121. Lam, K.L.; Lant, P.A.; O'Brien, K.R.; Kenway, S.J. Comparison of water-energy trajectories of two major regions experiencing water shortage. J. Environ. Manag. 2016, 181, 403-412. [CrossRef]

122. Brent, A.; Mokheseng, M.; Amigun, B.; Tazvinga, H.; Musango, J. Systems dynamics modelling to assess the sustainability of renewable energy technologies in developing countries. WIT Trans. Ecol. Environ. 2011, 143, 13-24. [CrossRef]

123. Gibbons, J.; Papapetrou, M.; Epp, C. Assessment of EU policy: Implications for the implementation of autonomous desalination units powered by renewable resources in the Mediterranean region. Desalination 2008, 220, 422-430. [CrossRef]

124. Sozen, S.; Teksoy, S.; Papapetrou, M. Assessment of institutional and policy conditions in Turkey: Implications for the implementation of autonomous desalination systems. Desalination 2008, 220, 441-454. [CrossRef]

125. Siddiqi, A.; Kajenthira, A.; Anadon, L.D. Bridging decision networks for integrated water and energy planning. Energy Strategy Rev. 2013, 2, 46-58. [CrossRef]

126. Foteinis, S.; Tsoutsos, T. Strategies to improve sustainability and offset the initial high capital expenditure of wave energy converters (WECs). Renew. Sustain. Energy Rev. 2017, 70, 775-785. [CrossRef]

127. Azhar, M.; Rizvi, G.; Dincer, I. Integration of renewable energy based multigeneration system with desalination. Desalination 2017, 404, 72-78. [CrossRef]

128. Sahin, O.; Siems, R.; Richards, R.; Helfer, F.; Stewart, R. Examining the potential for energy-positive bulk-water infrastructure to provide long-term urban water security: A systems approach. J. Clean. Prod. 2017, 143, 557-566. [CrossRef]

129. Gulagi, A.; Choudhary, P.; Bogdanov, D.; Breyer, C. Electricity system based on $100 \%$ renewable energy for India and SAARC. PLoS ONE 2017, 12, e0180611. [CrossRef] 
130. Mollahosseini, A.; Abdelrasoul, A.; Sheibany, S.; Amini, M.; Salestan, S. Renewable energy-driven desalination opportunities-A case study. J. Environ. Manag. 2019, 239, 187-197. [CrossRef]

131. Artz, G.M.; Hoque, M.; Orazem, P.F.; Shah, U. Urban-Rural Wage Gaps, Inefficient Labor Allocations, and GDP per Capita, Iowa State University Digital Repository. 2016. Available online: https://lib.dr.iastate. edu / cgi/viewcontent.cgi?article=1006\&context=econ_workingpapers (accessed on 24 June 2020).

132. Mossad, M.; Zhang, W.; Zou, L. Using capacitive deionisation for inland brackish groundwater desalination in a remote location. Desalination 2013, 308, 154-160. [CrossRef]

133. Zhang, W.; Mossad, M.; Zou, L. A study of the long-term operation of capacitive deionisation in inland brackish water desalination. Desalination 2013, 320, 80-85. [CrossRef]

134. Jia, B.; Zhang, W. Preparation and application of electrodes in capacitive deionization (CDI): A state-of-art review. Nanoscale Res. Lett. 2016, 11, 64. [CrossRef]

(c) 2020 by the authors. Licensee MDPI, Basel, Switzerland. This article is an open access article distributed under the terms and conditions of the Creative Commons Attribution (CC BY) license (http://creativecommons.org/licenses/by/4.0/). 